Supplement of Atmos. Chem. Phys., 19, 5005-5020, 2019

https://doi.org/10.5194/acp-19-5005-2019-supplement

(c) Author(s) 2019. This work is distributed under

the Creative Commons Attribution 4.0 License.

(c) (i)

Supplement of

\title{
Identification of soil-cooling rains in southern France from soil temperature and soil moisture observations
}

Sibo Zhang et al.

Correspondence to: Jean-Christophe Calvet (jean-christophe.calvet@meteo.fr)

The copyright of individual parts of the supplement might differ from the CC BY 4.0 License. 


\section{Fraction of missing data of in situ observations}

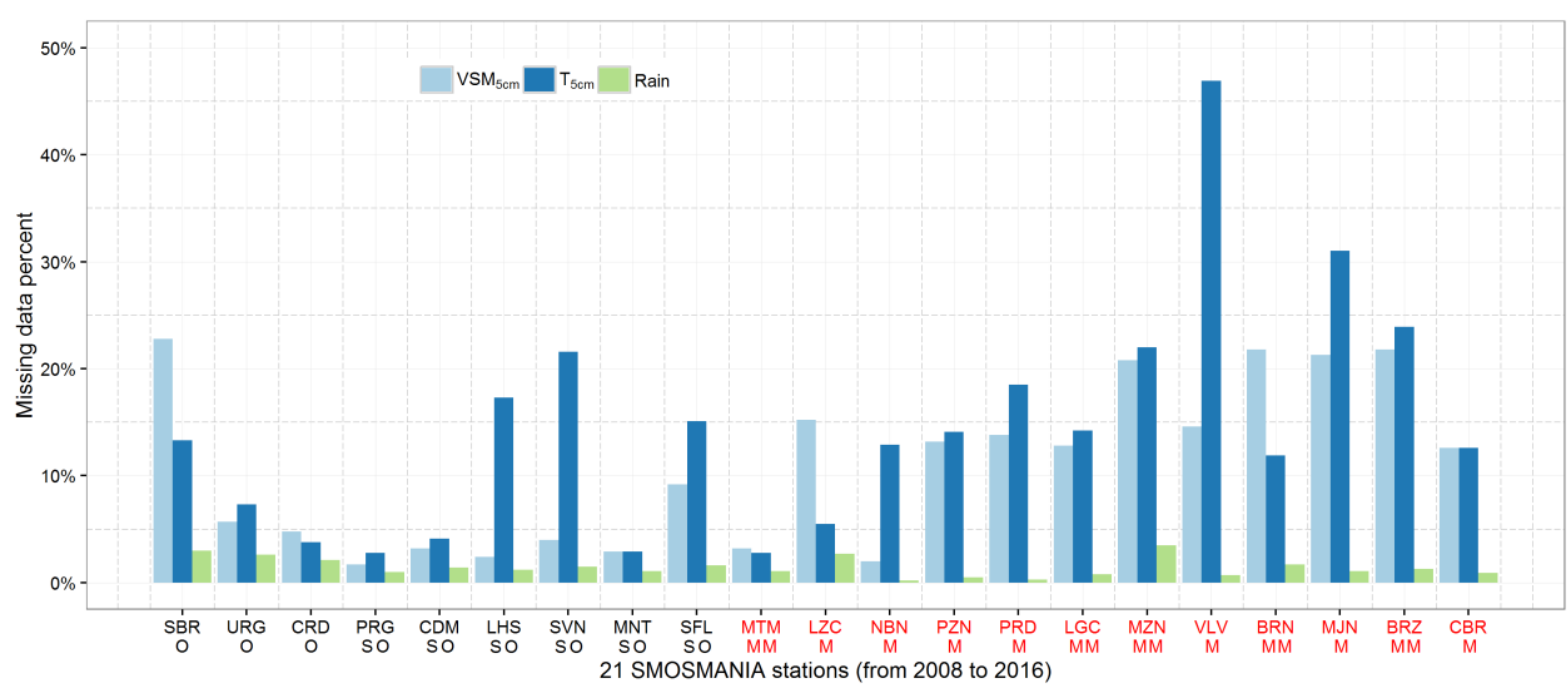

Figure S1. Fraction of missing data for in situ $\operatorname{VSM}_{5 \mathrm{~cm}}$ (light blue), $\mathrm{T}_{5 \mathrm{~cm}}$ (dark blue) and Rain observations measured every $12 \mathrm{~min}$ for the 21 SMOSMANIA stations from 2008 to 2016. Stations are sorted from (left) West to (right) East. Symbols "O", "SO", "M", and "MM" indicate Oceanic, Semi-Oceanic, Mediterranean, and Mediterranean/Mountain climates, respectively.

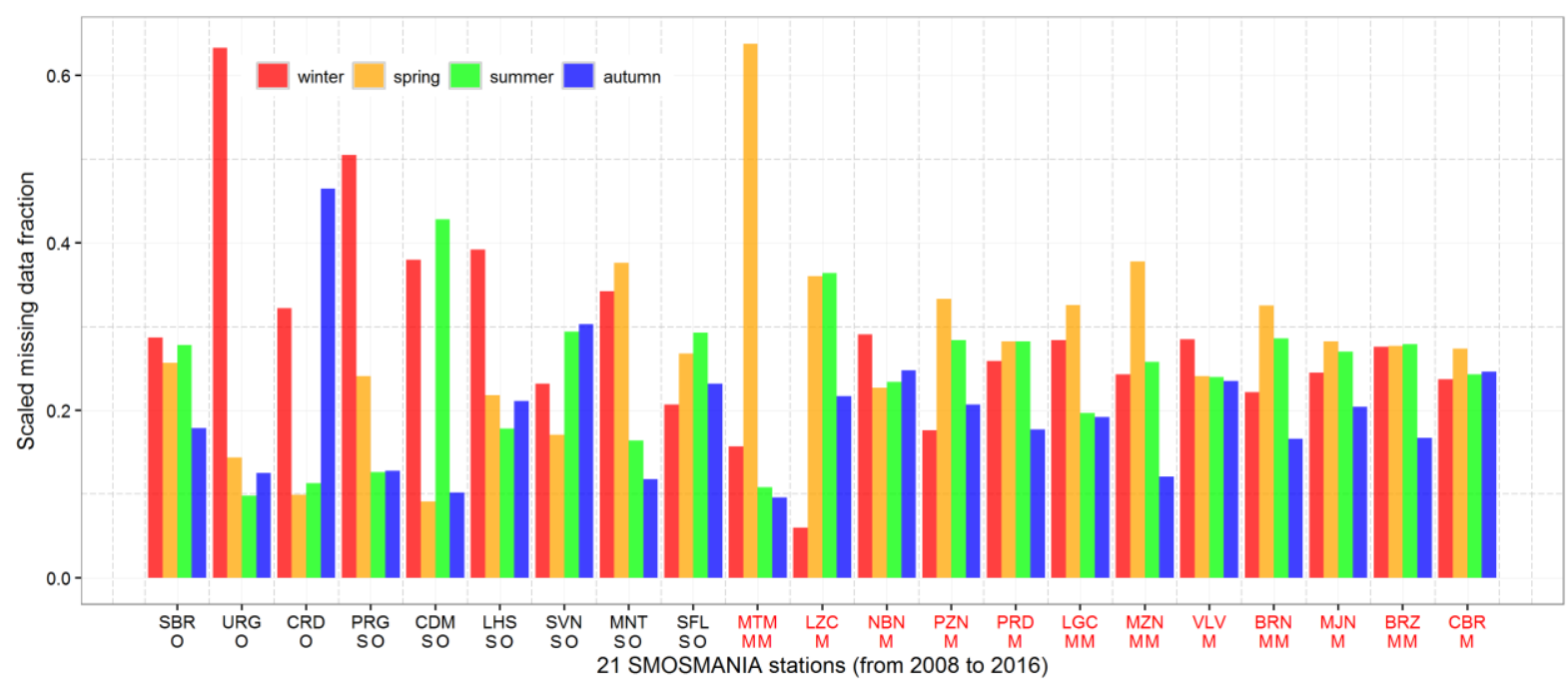

Figure S2. Scaled seasonal distribution of the fraction of missing data of either $\mathrm{VSM}_{5 \mathrm{~cm}}$ or $\mathrm{T}_{5 \mathrm{~cm}}$ for the 21 SMOSMANIA stations (winter, spring, summer, autumn, corresponding to December-JanuaryFebruary, March-April-May, June-July-August, September-October-November, respectively). Stations are sorted from (left) West to (right) East. Symbols "O", "SO", "M", and "MM" indicate Oceanic, SemiOceanic, Mediterranean, and Mediterranean/Mountain climates, respectively. 
Table S1. Fraction of missing data, from 0 to 1 , of either $\mathrm{VSM}_{5 \mathrm{~cm}}$ or $\mathrm{T}_{5 \mathrm{~cm}}$ for the 21 SMOSMANIA stations and its seasonal distribution in \% (winter, spring, summer, autumn, corresponding to December-January-February, March-April-May, June-July-August, September-October-November, respectively). Fractions larger than 0.1 are in bold. Seasonal grouping of missing data larger than $40 \%$ is in bold. Stations are sorted from (top) West to (bottom) East.

\begin{tabular}{|lccccc|}
\multicolumn{1}{c}{$\begin{array}{c}\text { Station (full name) } \\
\text { of missing data }\end{array}$} & & & & Sultumn \\
SBR (Sabres) & 0.24 & $29 \%$ & $26 \%$ & $28 \%$ & $18 \%$ \\
\hline URG (Urgons) & 0.07 & $64 \%$ & $15 \%$ & $9 \%$ & $12 \%$ \\
\hline CRD (Créon d'Armagnac) & 0.06 & $32 \%$ & $11 \%$ & $11 \%$ & $47 \%$ \\
\hline PRG (Peyrusse Grande) & 0.03 & $48 \%$ & $24 \%$ & $14 \%$ & $14 \%$ \\
\hline CDM (Condom) & 0.04 & $38 \%$ & $10 \%$ & $43 \%$ & $10 \%$ \\
\hline LHS (Lahas) & 0.18 & $39 \%$ & $22 \%$ & $18 \%$ & $21 \%$ \\
\hline SVN (Savenès) & 0.23 & $23 \%$ & $17 \%$ & $29 \%$ & $30 \%$ \\
\hline MNT (Montaut) & 0.03 & $34 \%$ & $38 \%$ & $17 \%$ & $10 \%$ \\
\hline SFL (Saint-Félix-de-Lauragais) & 0.19 & $21 \%$ & $27 \%$ & $29 \%$ & $23 \%$ \\
\hline MTM (Mouthoumet) & 0.05 & $16 \%$ & $64 \%$ & $10 \%$ & $10 \%$ \\
\hline LZC (Lézignan-Corbières) & 0.16 & $6 \%$ & $36 \%$ & $36 \%$ & $22 \%$ \\
\hline NBN (Narbonne) & 0.13 & $29 \%$ & $22 \%$ & $23 \%$ & $25 \%$ \\
\hline PZN (Pézenas) & 0.14 & $18 \%$ & $33 \%$ & $28 \%$ & $21 \%$ \\
\hline PRD (Prades-le-Lez) & 0.20 & $26 \%$ & $28 \%$ & $28 \%$ & $18 \%$ \\
\hline LGC (La-Grand-Combe) & 0.15 & $28 \%$ & $33 \%$ & $20 \%$ & $19 \%$ \\
\hline MZN (Mazan-L'Abbaye) & 0.23 & $24 \%$ & $38 \%$ & $26 \%$ & $12 \%$ \\
\hline VLV (Villevieille) & 0.48 & $29 \%$ & $24 \%$ & $24 \%$ & $24 \%$ \\
\hline BRN (Barnas) & 0.22 & $22 \%$ & $32 \%$ & $29 \%$ & $16 \%$ \\
\hline MJN (Méjannes-le-Clap) & 0.31 & $24 \%$ & $28 \%$ & $27 \%$ & $20 \%$ \\
\hline BRZ (Berzème) & 0.31 & $28 \%$ & $28 \%$ & $28 \%$ & $17 \%$ \\
\hline CBR (Cabrières-d'Avignon) & 0.13 & $24 \%$ & $28 \%$ & $24 \%$ & $24 \%$ \\
\hline & & & & & \\
\hline Mean value & 0.17 & $29 \%$ & $28 \%$ & $24 \%$ & $20 \%$ \\
\hline
\end{tabular}




\section{Soil characteristics}

Table S2. Reconstructed soil characteristics at a depth of $5 \mathrm{~cm}$ for the 21 stations of the SMOSMANIA network, assuming a zero fraction of gravels. Stations are sorted from (top) West to (bottom) East.

\begin{tabular}{|ccccccc|}
\hline Station & $\begin{array}{c}V_{\text {SMM }} \\
\left(\mathrm{m}^{3} \mathrm{~m}^{-3}\right)\end{array}$ & $\begin{array}{c}f_{\text {sand }} \\
\left(\mathrm{m}^{3} \mathrm{~m}^{-3}\right)\end{array}$ & $\begin{array}{c}f_{\text {clay }} \\
\left(\mathrm{m}^{3} \mathrm{~m}^{-3}\right)\end{array}$ & $\begin{array}{c}f_{\text {silt }} \\
\left(\mathrm{m}^{3} \mathrm{~m}^{-3}\right)\end{array}$ & $\begin{array}{c}f_{\text {oravel }} \\
\left(\mathrm{m}^{3} \mathrm{~m}^{-3}\right)\end{array}$ & $\begin{array}{c}f_{\text {som }} \\
\left(\mathrm{m}^{3} \mathrm{~m}^{-3}\right)\end{array}$ \\
\hline SBR & 0.440 & 0.502 & 0.021 & 0.016 & 0 & 0.021 \\
\hline URG & 0.472 & 0.079 & 0.078 & 0.341 & 0 & 0.029 \\
\hline CRD & 0.487 & 0.413 & 0.027 & 0.029 & 0 & 0.045 \\
\hline PRG & 0.497 & 0.073 & 0.193 & 0.197 & 0 & 0.039 \\
\hline CDM & 0.457 & 0.078 & 0.215 & 0.232 & 0 & 0.019 \\
\hline LHS & 0.413 & 0.154 & 0.196 & 0.205 & 0 & 0.032 \\
\hline SVN & 0.457 & 0.191 & 0.103 & 0.235 & 0 & 0.014 \\
\hline MNT & 0.453 & 0.145 & 0.077 & 0.290 & 0 & 0.036 \\
\hline SFL & 0.396 & 0.253 & 0.132 & 0.196 & 0 & 0.024 \\
\hline MTM & 0.419 & 0.211 & 0.148 & 0.144 & 0 & 0.079 \\
\hline LZC & 0.464 & 0.222 & 0.138 & 0.145 & 0 & 0.031 \\
\hline NBN & 0.495 & 0.116 & 0.206 & 0.122 & 0 & 0.060 \\
\hline PZN & 0.510 & 0.224 & 0.077 & 0.141 & 0 & 0.047 \\
\hline PRD & 0.460 & 0.130 & 0.150 & 0.202 & 0 & 0.057 \\
\hline LGC & 0.405 & 0.410 & 0.072 & 0.078 & 0 & 0.035 \\
\hline MZN & 0.600 & 0.219 & 0.049 & 0.056 & 0 & 0.075 \\
\hline VLV & 0.557 & 0.261 & 0.054 & 0.082 & 0 & 0.046 \\
\hline BRN & 0.424 & 0.385 & 0.047 & 0.066 & 0 & 0.078 \\
\hline MJN & 0.460 & 0.192 & 0.068 & 0.161 & 0 & 0.119 \\
\hline BRZ & 0.572 & 0.148 & 0.092 & 0.155 & 0 & 0.032 \\
\hline CBR & 0.488 & 0.222 & 0.113 & 0.132 & 0 & 0.045 \\
\hline
\end{tabular}


Table S3. Observed soil characteristics at a depth of $10 \mathrm{~cm}$ for the 21 stations of the SMOSMANIA network. Adapted from Table 1 in Calvet et al. (2016). Stations are sorted from (top) West to (bottom) East.

\begin{tabular}{|ccccccc|}
\hline Station & $\begin{array}{c}\mathrm{VSM}_{\text {sat }} \\
\left(\mathrm{m}^{3} \mathrm{~m}^{-3}\right)\end{array}$ & $\begin{array}{c}f_{\text {sand }} \\
\left(\mathrm{m}^{3} \mathrm{~m}^{-3}\right)\end{array}$ & $\begin{array}{c}f_{\text {clay }} \\
\left(\mathrm{m}^{3} \mathrm{~m}^{-3}\right)\end{array}$ & $\begin{array}{c}f_{\text {silt }} \\
\left(\mathrm{m}^{3} \mathrm{~m}^{-3}\right)\end{array}$ & $\begin{array}{c}f_{\text {oravel }} \\
\left(\mathrm{m}^{3} \mathrm{~m}^{-3}\right)\end{array}$ & $\begin{array}{c}f_{\text {som }} \\
\left(\mathrm{m}^{3} \mathrm{~m}^{-3}\right)\end{array}$ \\
\hline SBR & 0.352 & 0.576 & 0.026 & 0.013 & 0.002 & 0.032 \\
\hline URG & 0.474 & 0.076 & 0.078 & 0.341 & 0.005 & 0.025 \\
\hline CRD & 0.437 & 0.457 & 0.027 & 0.033 & 0.000 & 0.045 \\
\hline PRG & 0.431 & 0.051 & 0.138 & 0.138 & 0.214 & 0.028 \\
\hline CDM & 0.413 & 0.073 & 0.241 & 0.231 & 0.012 & 0.030 \\
\hline LHS & 0.416 & 0.102 & 0.202 & 0.189 & 0.051 & 0.039 \\
\hline SVN & 0.445 & 0.128 & 0.073 & 0.176 & 0.162 & 0.017 \\
\hline MNT & 0.447 & 0.135 & 0.066 & 0.230 & 0.102 & 0.020 \\
\hline SFL & 0.413 & 0.127 & 0.071 & 0.118 & 0.250 & 0.021 \\
\hline MTM & 0.405 & 0.110 & 0.081 & 0.076 & 0.297 & 0.032 \\
\hline LZC & 0.429 & 0.129 & 0.066 & 0.068 & 0.292 & 0.015 \\
\hline NBN & 0.401 & 0.063 & 0.135 & 0.075 & 0.290 & 0.036 \\
\hline PZN & 0.495 & 0.222 & 0.074 & 0.131 & 0.055 & 0.023 \\
\hline PRD & 0.494 & 0.038 & 0.052 & 0.069 & 0.326 & 0.021 \\
\hline LGC & 0.428 & 0.254 & 0.044 & 0.042 & 0.214 & 0.019 \\
\hline MZN & 0.560 & 0.212 & 0.037 & 0.045 & 0.097 & 0.049 \\
\hline VLV & 0.506 & 0.294 & 0.054 & 0.086 & 0.031 & 0.029 \\
\hline BRN & 0.379 & 0.105 & 0.009 & 0.016 & 0.474 & 0.016 \\
\hline MJN & 0.506 & 0.064 & 0.029 & 0.056 & 0.317 & 0.028 \\
\hline BRZ & 0.508 & 0.097 & 0.074 & 0.110 & 0.191 & 0.020 \\
\hline CBR & 0.501 & 0.120 & 0.057 & 0.068 & 0.241 & 0.013 \\
\hline
\end{tabular}




\section{Examples of significant soil-cooling rains}
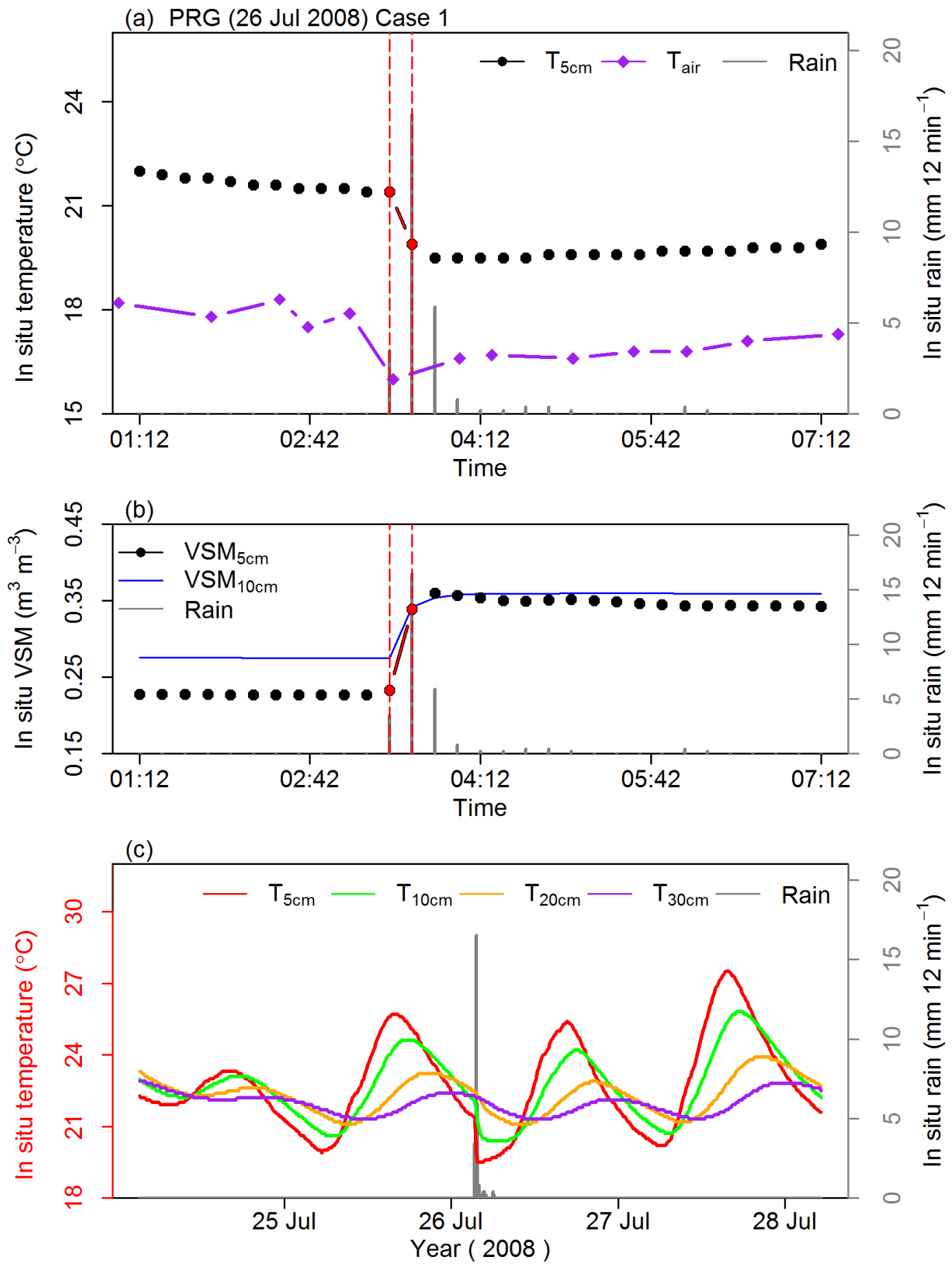

Figure S3. (a) In situ $\mathrm{T}_{5 \mathrm{~cm}}$ (black) and accumulated rainfall (grey) observations measured every 12 min, and the maximum and minimum $\mathrm{T}_{\text {air }}$ values in an hour (purple); (b) in situ $\mathrm{VSM}_{5 \mathrm{~cm}}$ (black), $\mathrm{VSM}_{10 \mathrm{~cm}}$ (blue) observations also measured every $12 \mathrm{~min}$, from case 1 (see Table 5) at PRG station on 26 July 2008. The red dashed lines show the duration from time $t_{1}$ to $t_{2}$, and the corresponding $\mathrm{T}_{5 \mathrm{~cm}}$ and $\mathrm{VSM}_{5 \mathrm{~cm}}$ are highlighted by red. (c) In situ soil temperature measured from 24 to 28 July 2008 at depths of 5, 10, 20 and $30 \mathrm{~cm}$, together with the in situ rainfall observations $\left(\mathrm{mm} 12 \mathrm{~min}^{-1}\right)$ shown in grey. 

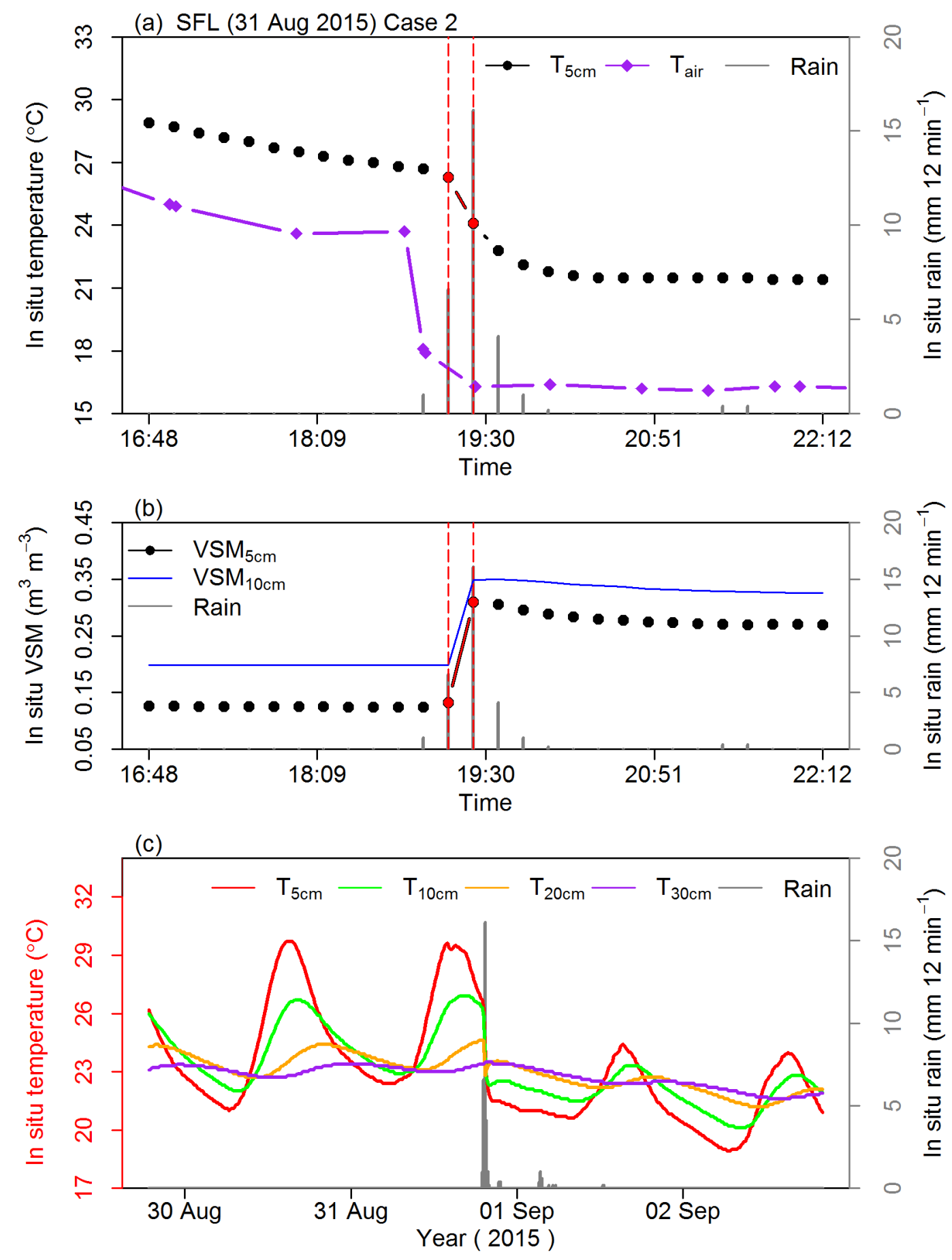

Figure S4. (a) In situ $\mathrm{T}_{5 \mathrm{~cm}}$ (black) and accumulated rainfall (grey) observations measured every 12 min, and the maximum and minimum $\mathrm{T}_{\text {air }}$ values in an hour (purple); (b) in situ $\mathrm{VSM}_{5 \mathrm{~cm}}$ (black), $\mathrm{VSM}_{10 \mathrm{~cm}}$ (blue) observations also measured every $12 \mathrm{~min}$, from case 2 (see Table 5) at SFL station on 31 August 2015. The red dashed lines show the duration from time $t_{1}$ to $t_{2}$, and the corresponding $\mathrm{T}_{5 \mathrm{~cm}}$ and $\mathrm{VSM}_{5 \mathrm{~cm}}$ are highlighted by red. (c) In situ soil temperature measured from 29 August to 2 September 2015 at depths of 5, 10, 20 and $30 \mathrm{~cm}$, together with the in situ rainfall observations (mm $12 \mathrm{~min}^{-1}$ ) shown in grey. 

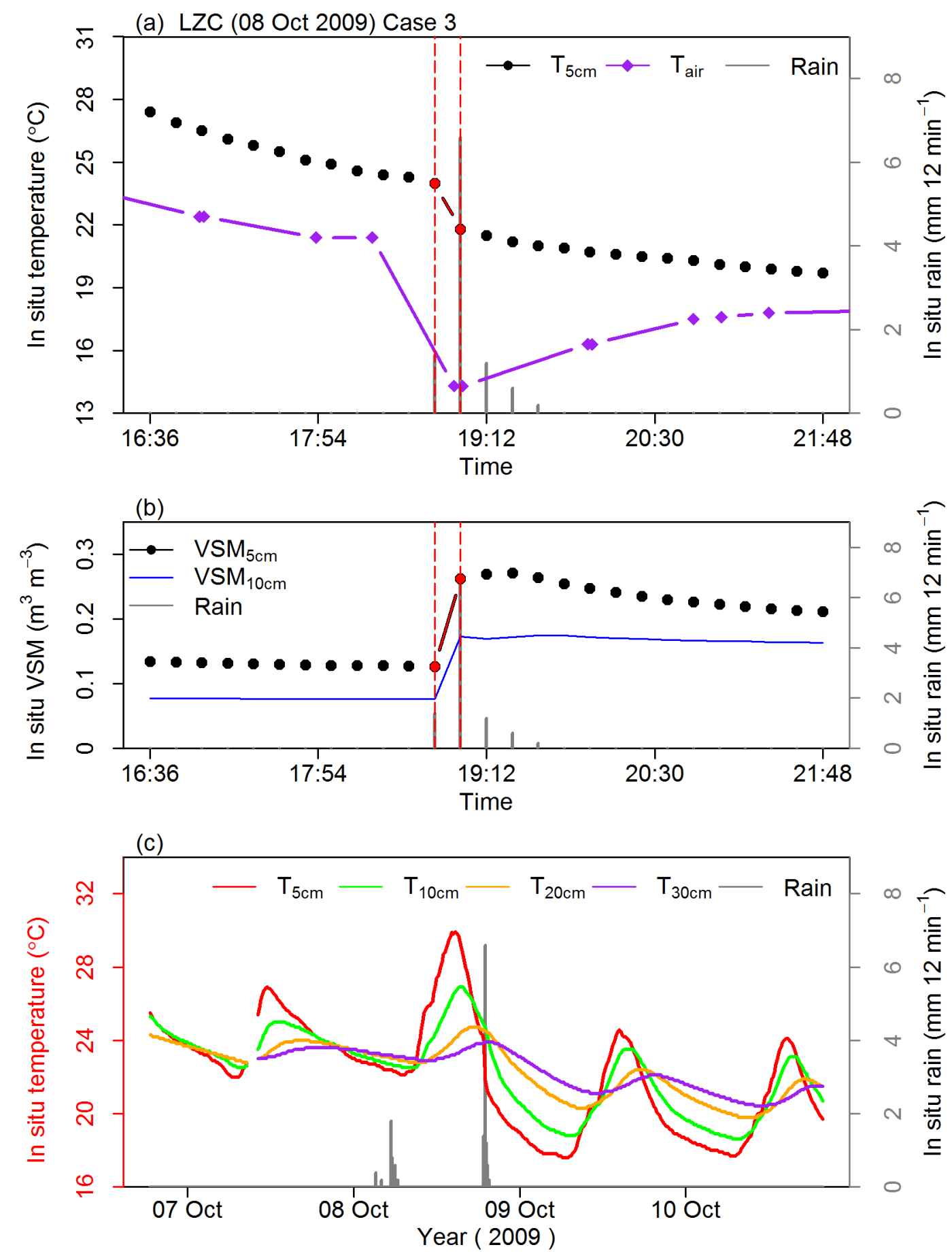

Figure S5. (a) In situ $\mathrm{T}_{5 \mathrm{~cm}}$ (black) and accumulated rainfall (grey) observations measured every 12 min, and the maximum and minimum $\mathrm{T}_{\text {air }}$ values in an hour (purple); (b) in situ $\mathrm{VSM}_{5 \mathrm{~cm}}$ (black), $\mathrm{VSM}_{10 \mathrm{~cm}}$ (blue) observations also measured every $12 \mathrm{~min}$, from case 3 (see Table 5) at LZC station on 8 October 2009. The red dashed lines show the duration from time $t_{1}$ to $t_{2}$, and the corresponding $\mathrm{T}_{5 \mathrm{~cm}}$ and $\mathrm{VSM}_{5 \mathrm{~cm}}$ are highlighted by red. (c) In situ soil temperature measured from 6 to 10 October 2009 at depths of $5,10,20$ and $30 \mathrm{~cm}$, together with the in situ rainfall observations $\left(\mathrm{mm} 12 \mathrm{~min}^{-1}\right)$ shown in grey. 

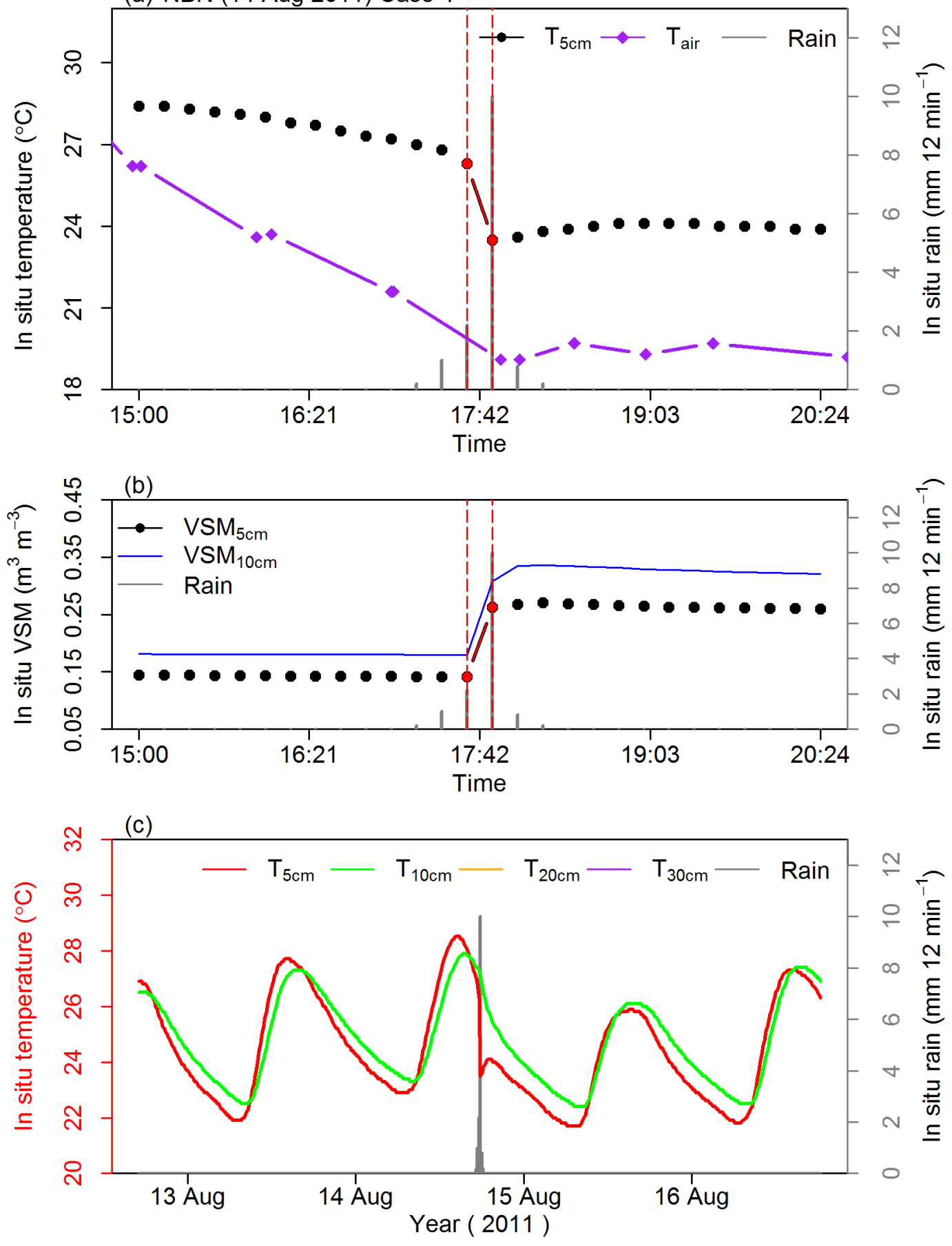

Figure S6. (a) In situ $\mathrm{T}_{5 \mathrm{~cm}}$ (black) and accumulated rainfall (grey) observations measured every 12 min, and the maximum and minimum $\mathrm{T}_{\text {air }}$ values in an hour (purple); (b) in situ $\mathrm{VSM}_{5 \mathrm{~cm}}$ (black), $\mathrm{VSM}_{10 \mathrm{~cm}}$ (blue) observations also measured every $12 \mathrm{~min}$, from case 4 (see Table 5) at NBN station on 14 August 2011. The red dashed lines show the duration from time $t_{1}$ to $t_{2}$, and the corresponding $\mathrm{T}_{5 \mathrm{~cm}}$ and $\mathrm{VSM}_{5 \mathrm{~cm}}$ are highlighted by red. (c) In situ soil temperature measured from 12 to 16 August 2011 at depths of 5, 10, 20 and $30 \mathrm{~cm}$, together with the in situ rainfall observations $\left(\mathrm{mm} 12 \mathrm{~min}^{-1}\right)$ shown in grey. In situ soil temperatures at depths of 20 and $30 \mathrm{~cm}$ are missing. 

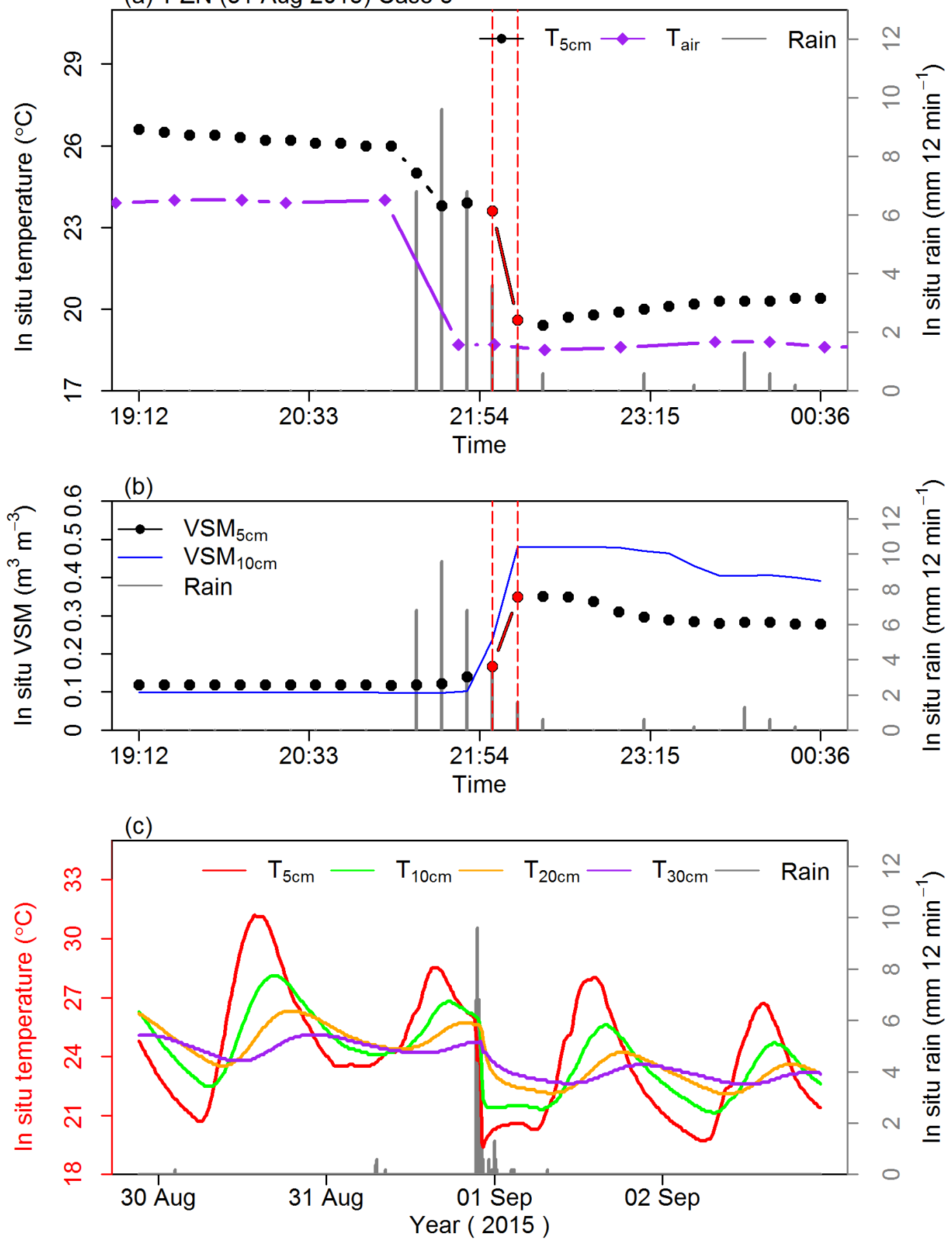

Figure S7. (a) In situ $\mathrm{T}_{5 \mathrm{~cm}}$ (black) and accumulated rainfall (grey) observations measured every 12 min, and the maximum and minimum $\mathrm{T}_{\text {air }}$ values in an hour (purple); (b) in situ $\mathrm{VSM}_{5 \mathrm{~cm}}$ (black), $\mathrm{VSM}_{10 \mathrm{~cm}}$ (blue) observations also measured every $12 \mathrm{~min}$, from case 5 (see Table 5) at PZN station on 31 August 2015. The red dashed lines show the duration from time $t_{1}$ to $t_{2}$, and the corresponding $\mathrm{T}_{5 \mathrm{~cm}}$ and $\mathrm{VSM}_{5 \mathrm{~cm}}$ are highlighted by red. (c) In situ soil temperature measured from 29 August to 2 September 2015 at depths of 5, 10, 20 and $30 \mathrm{~cm}$, together with the in situ rainfall observations (mm $12 \mathrm{~min}^{-1}$ ) shown in grey. 
(a) PRD (12 Jul 2011) Case 6
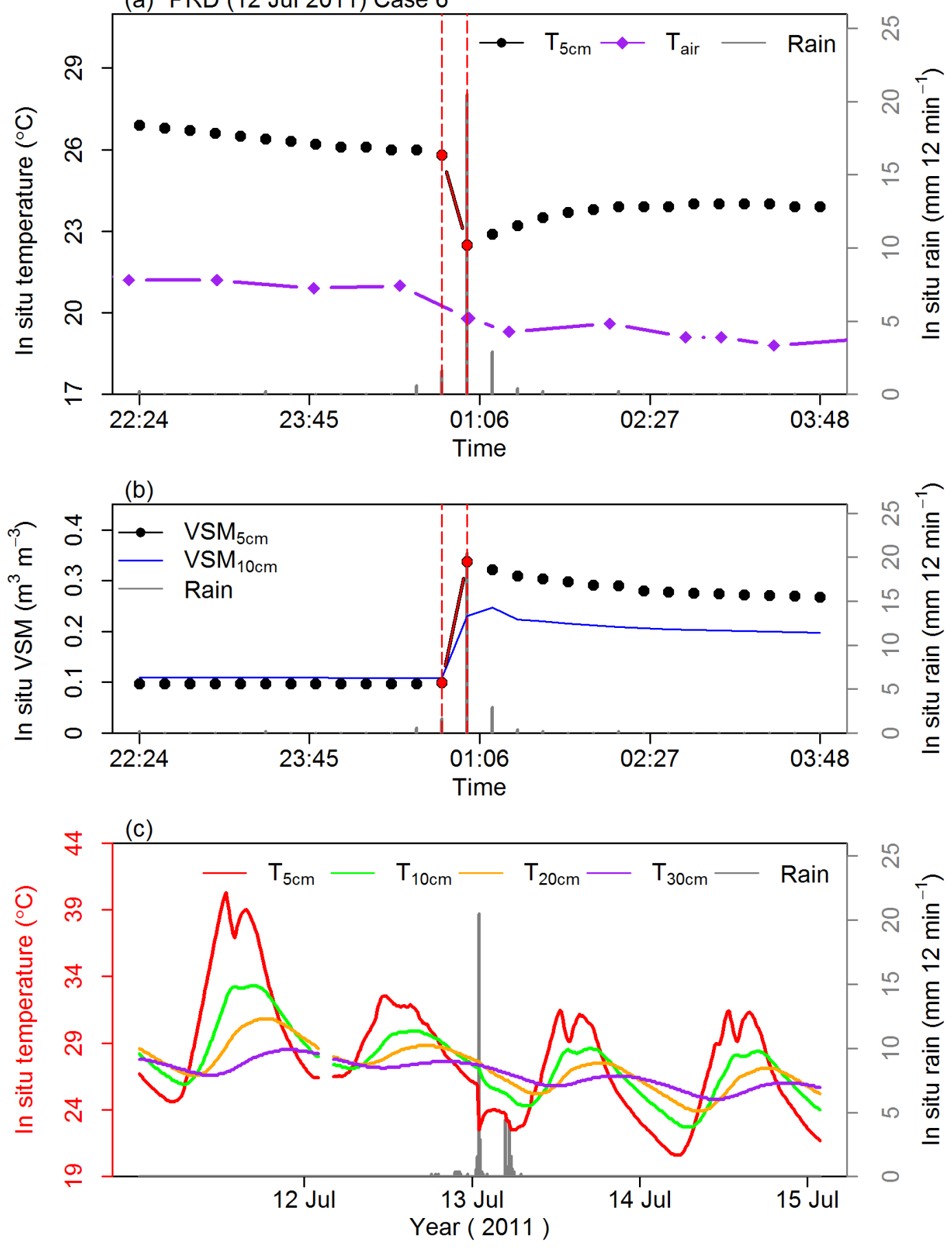

Figure S8. (a) In situ $\mathrm{T}_{5 \mathrm{~cm}}$ (black) and accumulated rainfall (grey) observations measured every 12 min, and the maximum and minimum $\mathrm{T}_{\text {air }}$ values in an hour (purple); (b) in situ $\mathrm{VSM}_{5 \mathrm{~cm}}$ (black), $\mathrm{VSM}_{10 \mathrm{~cm}}$ (blue) observations also measured every $12 \mathrm{~min}$, from case 6 (see Table 5) at PRD station on 12 and 13 July 2011. The red dashed lines show the duration from time $t_{1}$ to $t_{2}$, and the corresponding $\mathrm{T}_{5 \mathrm{~cm}}$ and $\mathrm{VSM}_{5 \mathrm{~cm}}$ are highlighted by red. (c) In situ soil temperature measured from 11 to 15 July 2011 at depths of 5, 10, 20 and $30 \mathrm{~cm}$, together with the in situ rainfall observations ( $\mathrm{mm} 12 \mathrm{~min}^{-1}$ ) shown in grey. 

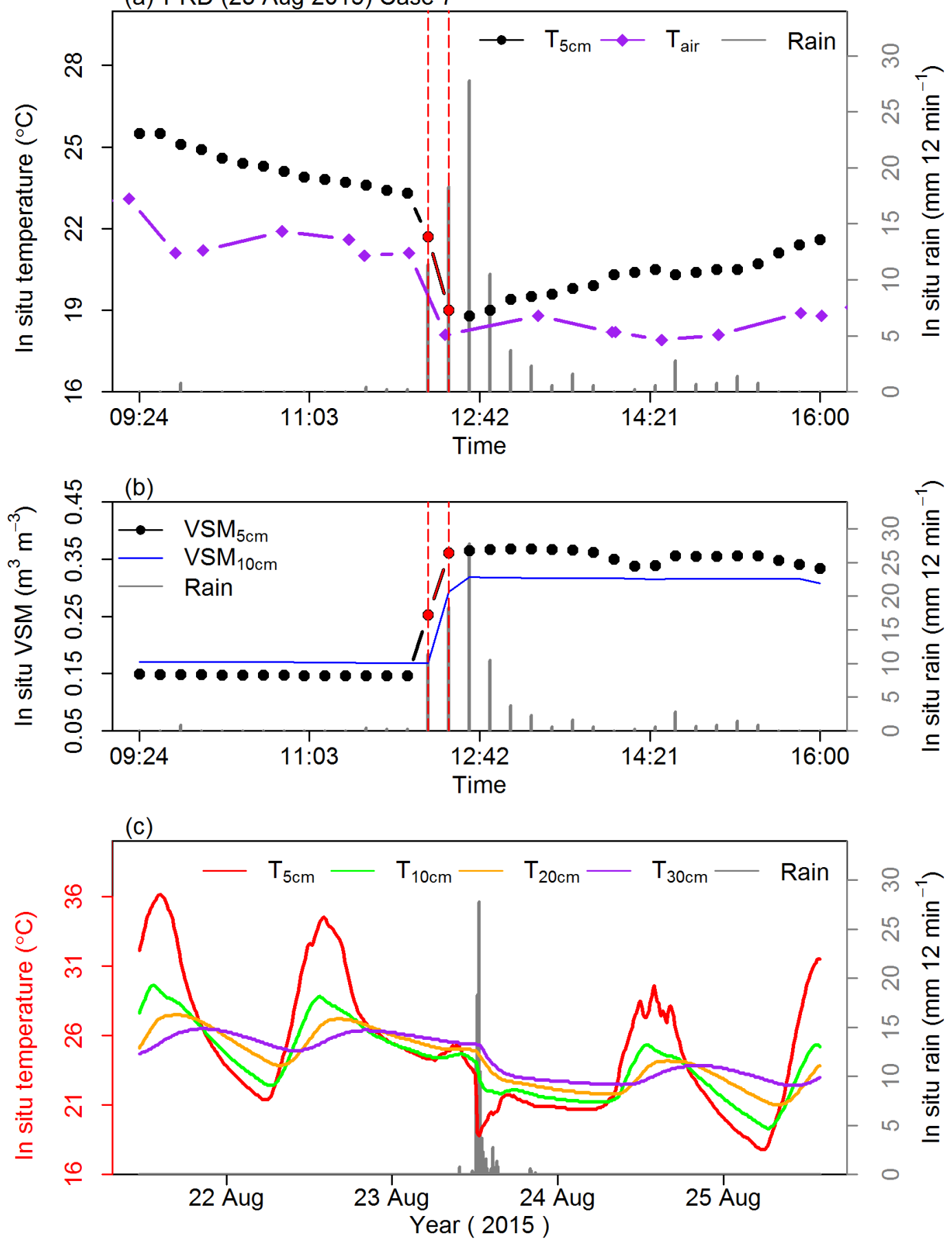

Figure S9. (a) In situ $\mathrm{T}_{5 \mathrm{~cm}}$ (black) and accumulated rainfall (grey) observations measured every 12 min, and the maximum and minimum $\mathrm{T}_{\text {air }}$ values in an hour (purple); (b) in situ $\mathrm{VSM}_{5 \mathrm{~cm}}$ (black), $\mathrm{VSM}_{10 \mathrm{~cm}}$ (blue) observations also measured every $12 \mathrm{~min}$, from case 7 (see Table 5) at PRD station on 23 August 2015. The red dashed lines show the duration from time $t_{1}$ to $t_{2}$, and the corresponding $\mathrm{T}_{5 \mathrm{~cm}}$ and $\mathrm{VSM}_{5 \mathrm{~cm}}$ are highlighted by red. (c) In situ soil temperature measured from 21 to 25 August 2015 at depths of 5, 10, 20 and $30 \mathrm{~cm}$, together with the in situ rainfall observations $\left(\mathrm{mm} 12 \mathrm{~min}^{-1}\right)$ shown in grey. 

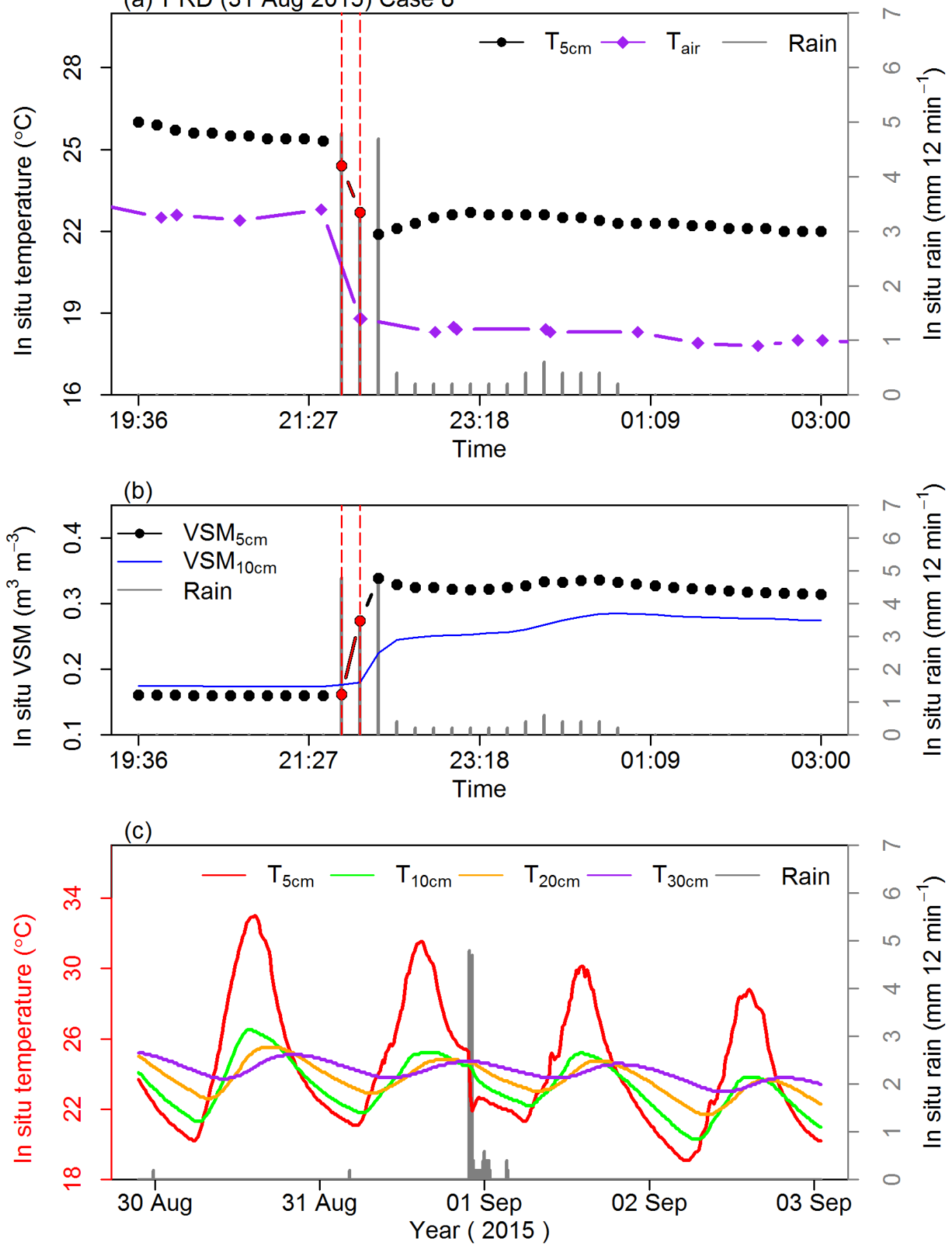

Figure S10. (a) In situ $\mathrm{T}_{5 \mathrm{~cm}}$ (black) and accumulated rainfall (grey) observations measured every 12 min, and the maximum and minimum $\mathrm{T}_{\text {air }}$ values in an hour (purple); (b) in situ $\mathrm{VSM}_{5 \mathrm{~cm}}$ (black), $\mathrm{VSM}_{10 \mathrm{~cm}}$ (blue) observations also measured every $12 \mathrm{~min}$, from case 8 (see Table 5) at PRD station on 31 August and 1 September 2015. The red dashed lines show the duration from time $t_{1}$ to $t_{2}$, and the corresponding $\mathrm{T}_{5 \mathrm{~cm}}$ and $\mathrm{VSM}_{5 \mathrm{~cm}}$ are highlighted by red. (c) In situ soil temperature measured from 29 August to 3 September 2015 at depths of 5, 10, 20 and $30 \mathrm{~cm}$, together with the in situ rainfall observations $\left(\mathrm{mm} 12 \mathrm{~min}^{-1}\right)$ shown in grey. 

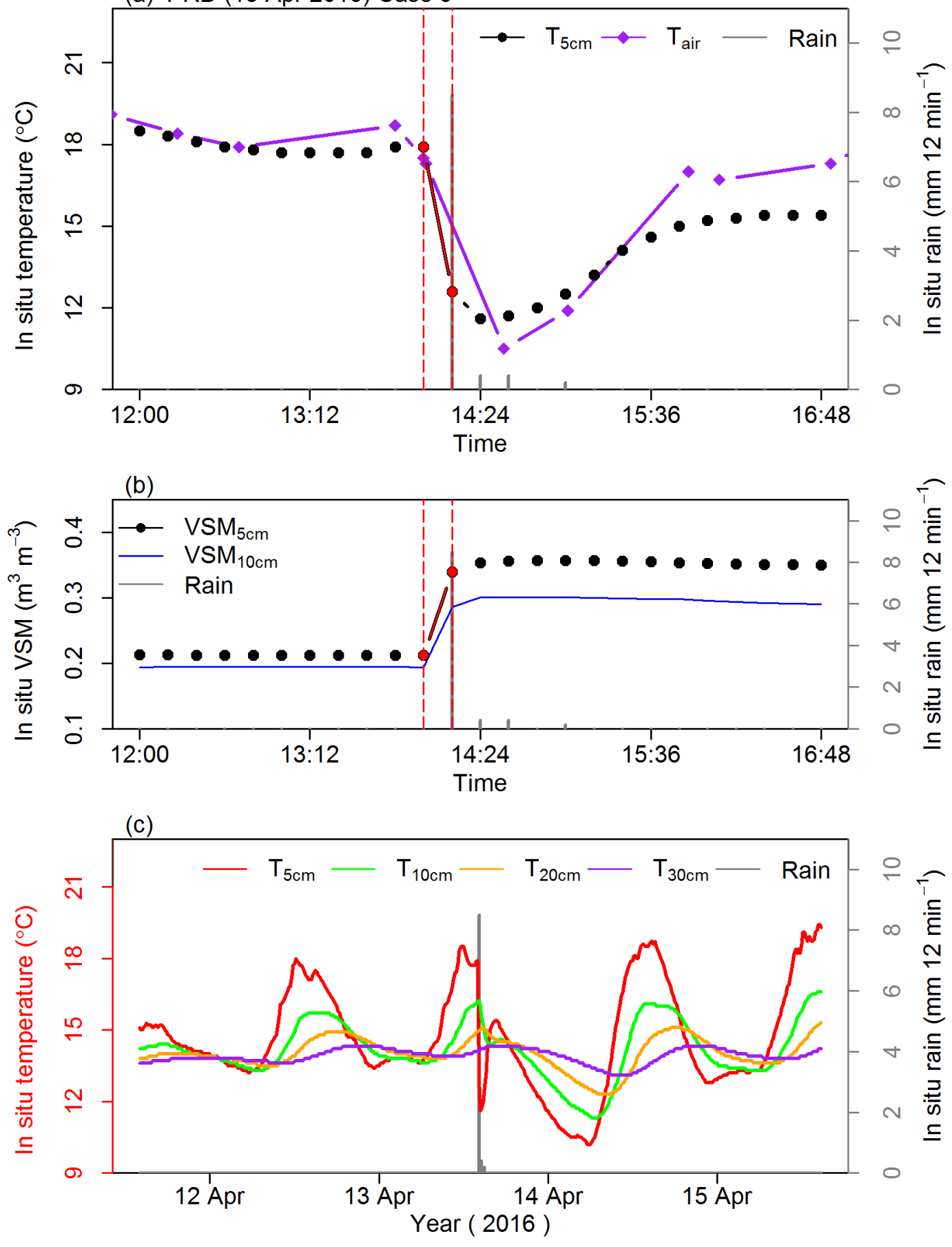

Figure S11. (a) In situ $\mathrm{T}_{5 \mathrm{~cm}}$ (black) and accumulated rainfall (grey) observations measured every 12 min, and the maximum and minimum $\mathrm{T}_{\text {air }}$ values in an hour (purple); (b) in situ $\mathrm{VSM}_{5 \mathrm{~cm}}$ (black), $\mathrm{VSM}_{10 \mathrm{~cm}}$ (blue) observations also measured every $12 \mathrm{~min}$, from case 9 (see Table 5) at PRD station on 13 April 2016. The red dashed lines show the duration from time $t_{1}$ to $t_{2}$, and the corresponding $\mathrm{T}_{5 \mathrm{~cm}}$ and $\mathrm{VSM}_{5 \mathrm{~cm}}$ are highlighted by red. (c) In situ soil temperature measured from 11 to 15 April 2016 at depths of 5, 10, 20 and $30 \mathrm{~cm}$, together with the in situ rainfall observations $\left(\mathrm{mm} 12 \mathrm{~min}^{-1}\right)$ shown in grey. 
(a) PRD (15 Jun 2016) Case 10
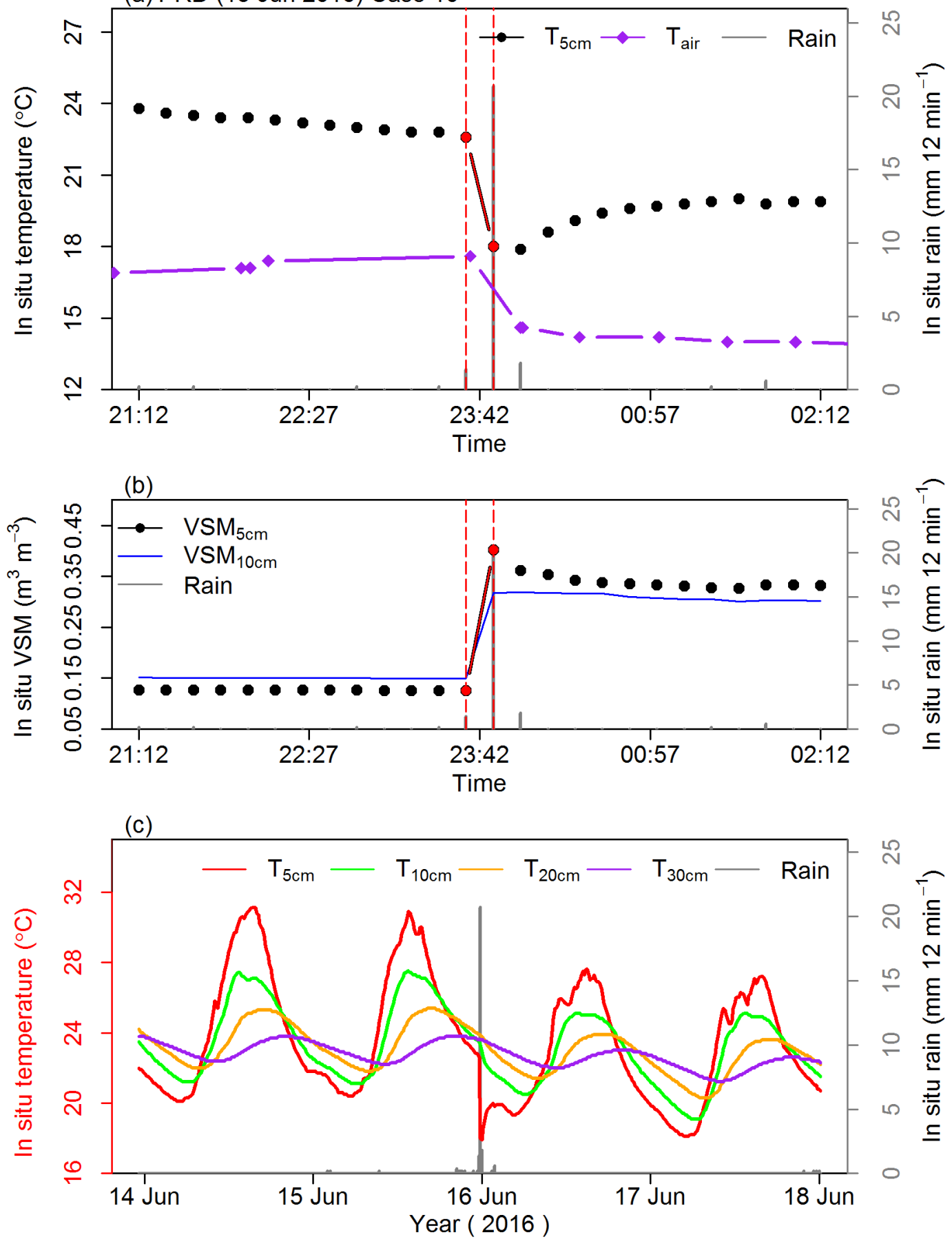

Figure S12. (a) In situ $\mathrm{T}_{5 \mathrm{~cm}}$ (black) and accumulated rainfall (grey) observations measured every 12 min, and the maximum and minimum $\mathrm{T}_{\text {air }}$ values in an hour (purple); (b) in situ $\mathrm{VSM}_{5 \mathrm{~cm}}$ (black), $\mathrm{VSM}_{10 \mathrm{~cm}}$ (blue) observations also measured every $12 \mathrm{~min}$, from case 10 (see Table 5) at PRD station on 15 and 16 June 2016. The red dashed lines show the duration from time $t_{1}$ to $t_{2}$, and the corresponding $\mathrm{T}_{5 \mathrm{~cm}}$ and $\mathrm{VSM}_{5 \mathrm{~cm}}$ are highlighted by red. (c) In situ soil temperature measured from 13 to 18 June 2016 at depths of 5, 10, 20 and $30 \mathrm{~cm}$, together with the in situ rainfall observations (mm $12 \mathrm{~min}^{-1}$ ) shown in grey. 

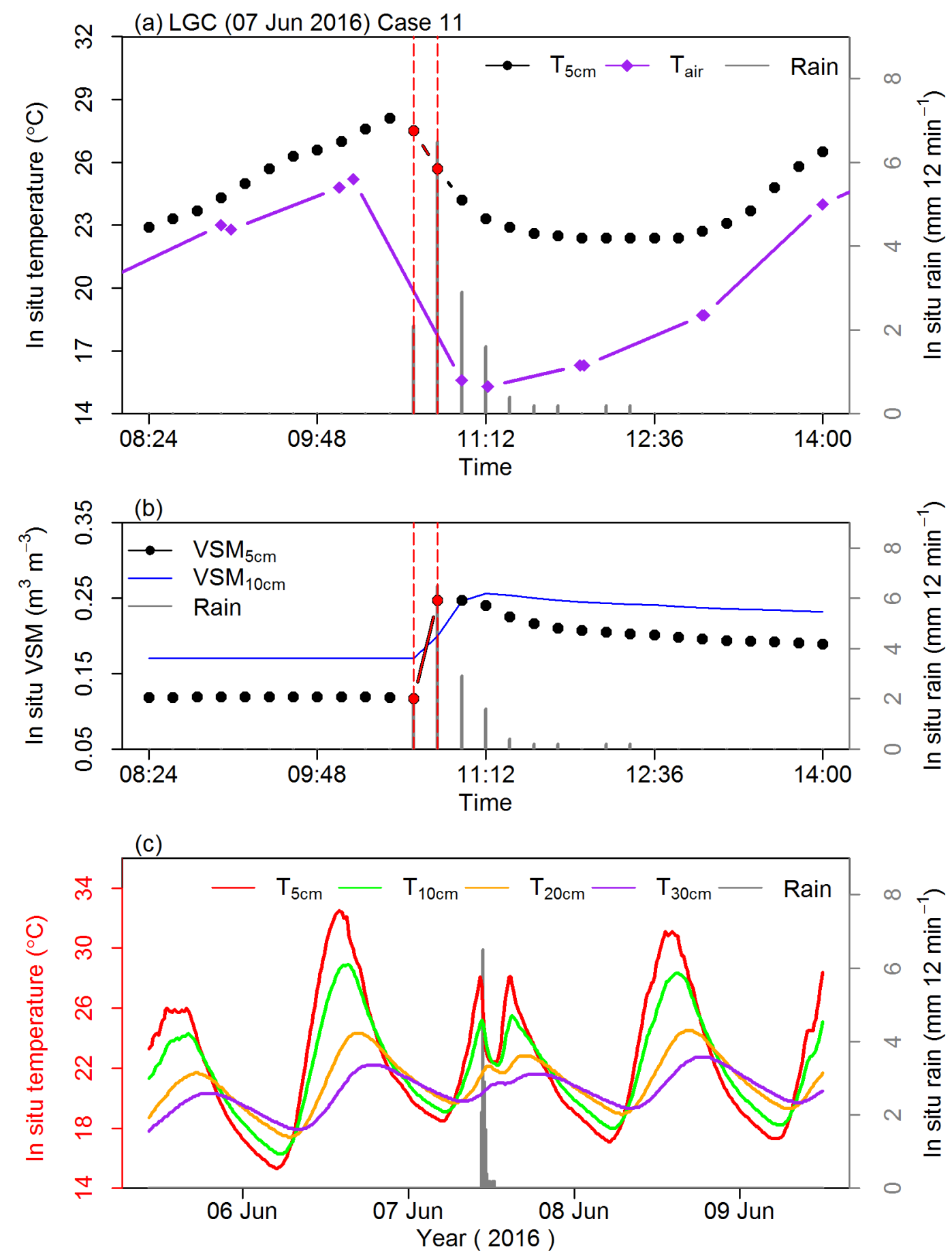

Figure S13. (a) In situ $\mathrm{T}_{5 \mathrm{~cm}}$ (black) and accumulated rainfall (grey) observations measured every 12 min, and the maximum and minimum $\mathrm{T}_{\text {air }}$ values in an hour (purple); (b) in situ $\mathrm{VSM}_{5 \mathrm{~cm}}$ (black), $\mathrm{VSM}_{10 \mathrm{~cm}}$ (blue) observations also measured every $12 \mathrm{~min}$, from case 11 (see Table 5) at LGC station on 7 June 2016. The red dashed lines show the duration from time $t_{1}$ to $t_{2}$, and the corresponding $\mathrm{T}_{5 \mathrm{~cm}}$ and $\mathrm{VSM}_{5 \mathrm{~cm}}$ are highlighted by red. (c) In situ soil temperature measured from 5 to 9 June 2016 at depths of 5, 10, 20 and $30 \mathrm{~cm}$, together with the in situ rainfall observations $\left(\mathrm{mm} 12 \mathrm{~min}^{-1}\right)$ shown in grey. 

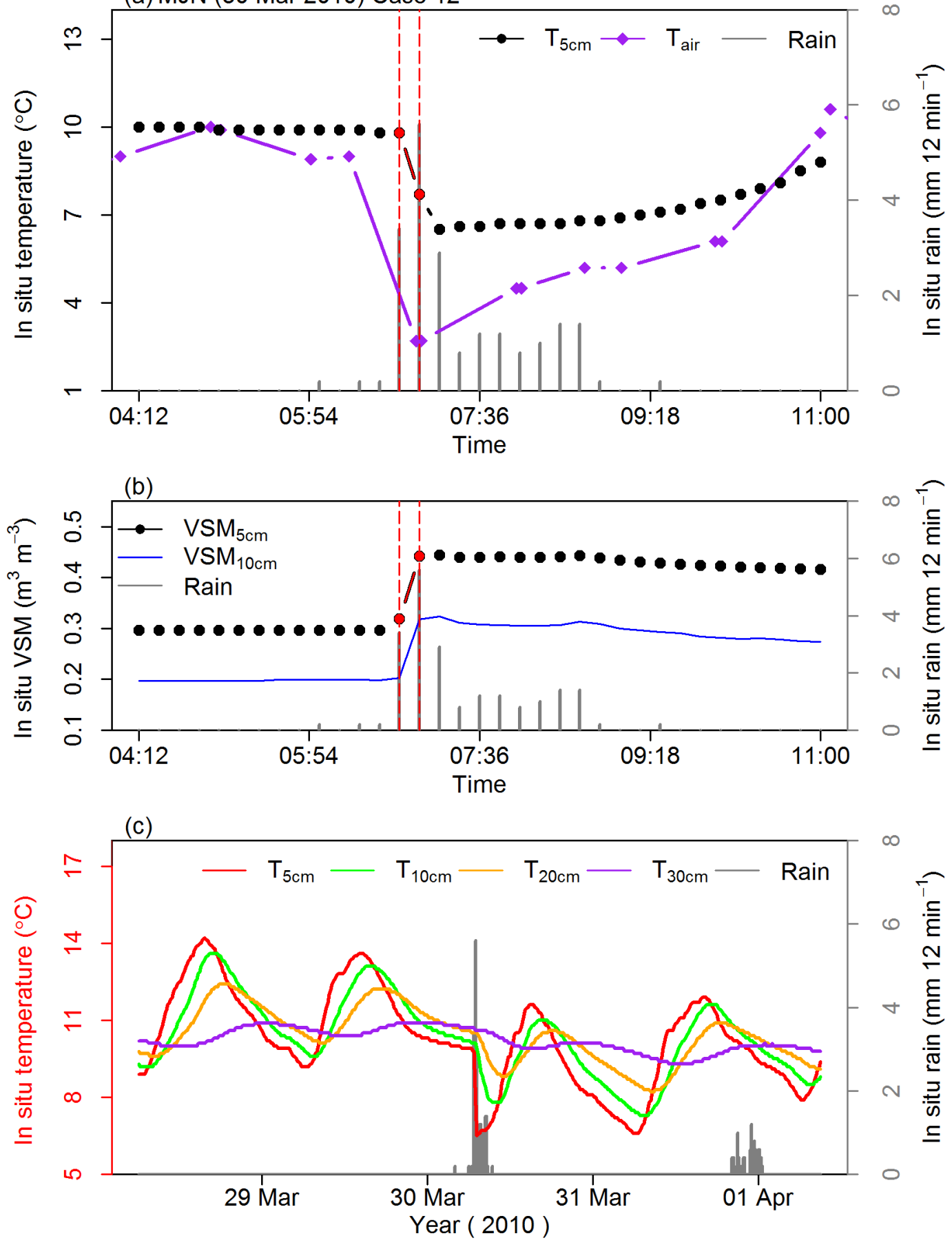

Figure S14. (a) In situ $\mathrm{T}_{5 \mathrm{~cm}}$ (black) and accumulated rainfall (grey) observations measured every 12 min, and the maximum and minimum $\mathrm{T}_{\text {air }}$ values in an hour (purple); (b) in situ $\mathrm{VSM}_{5 \mathrm{~cm}}$ (black), $\mathrm{VSM}_{10 \mathrm{~cm}}$ (blue) observations also measured every $12 \mathrm{~min}$, from case 12 (see Table 5) at MJN station on 30 March 2010. The red dashed lines show the duration from time $t_{1}$ to $t_{2}$, and the corresponding $\mathrm{T}_{5 \mathrm{~cm}}$ and $\mathrm{VSM}_{5 \mathrm{~cm}}$ are highlighted by red. (c) In situ soil temperature measured from 28 March to 1 April 2010 at depths of 5, 10, 20 and $30 \mathrm{~cm}$, together with the in situ rainfall observations $(\mathrm{mm} 12$ $\min ^{-1}$ ) shown in grey. 
(a) CBR (30 Jun 2010) Case 13
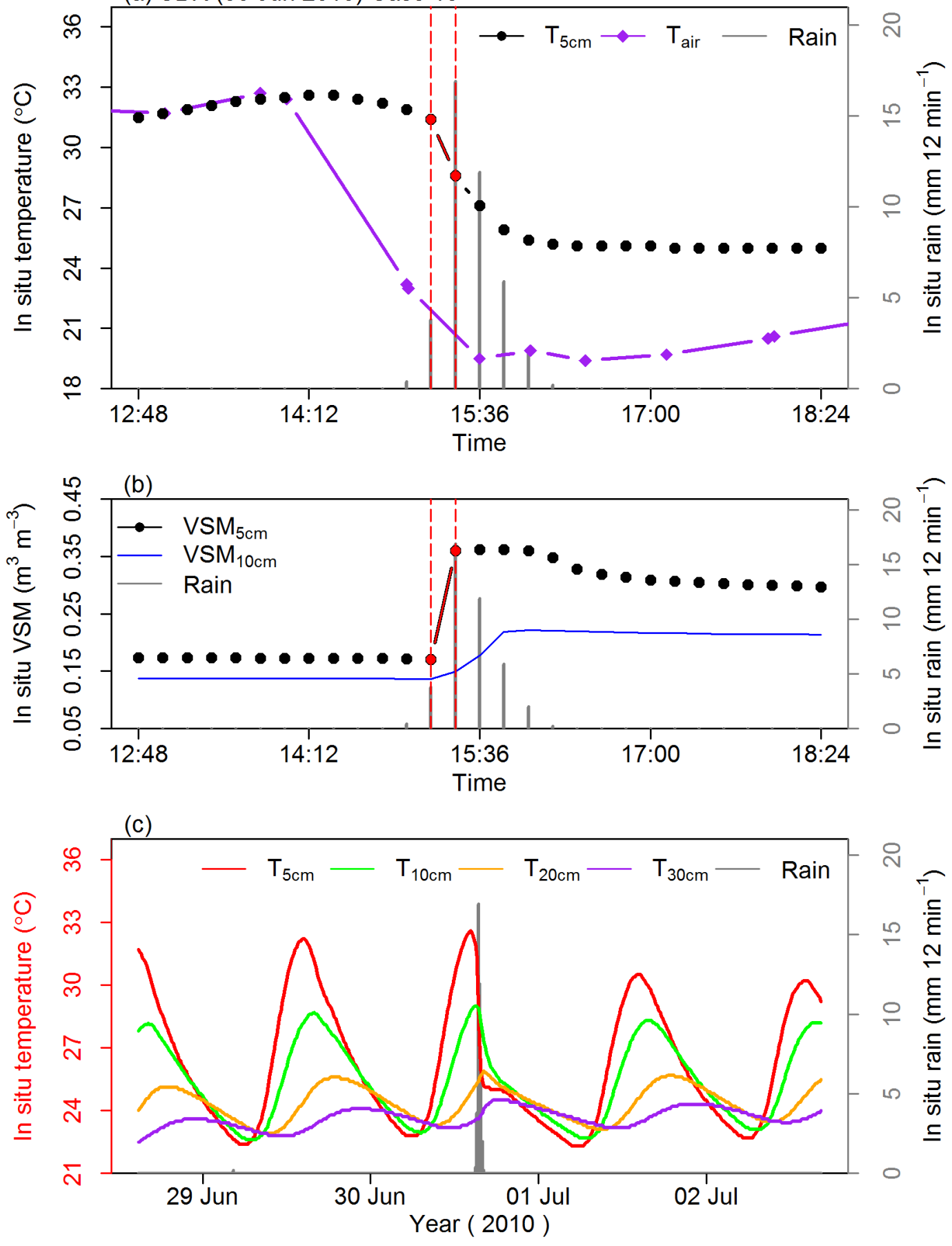

Figure S15. (a) In situ $\mathrm{T}_{5 \mathrm{~cm}}$ (black) and accumulated rainfall (grey) observations measured every 12 min, and the maximum and minimum $\mathrm{T}_{\text {air }}$ values in an hour (purple); (b) in situ $\mathrm{VSM}_{5 \mathrm{~cm}}$ (black), $\mathrm{VSM}_{10 \mathrm{~cm}}$ (blue) observations also measured every $12 \mathrm{~min}$, from case 13 (see Table 5) at CBR station on 30 June 2010. The red dashed lines show the duration from time $t_{1}$ to $t_{2}$, and the corresponding $\mathrm{T}_{5 \mathrm{~cm}}$ and $\mathrm{VSM}_{5 \mathrm{~cm}}$ are highlighted by red. (c) In situ soil temperature measured from 28 June to 2 July 2010 at depths of 5, 10, 20 and $30 \mathrm{~cm}$, together with the in situ rainfall observations $\left(\mathrm{mm} 12 \mathrm{~min}^{-1}\right)$ shown in grey. 
Examples of $\mathrm{VSM}_{5 \mathrm{~cm}}$ response to rain
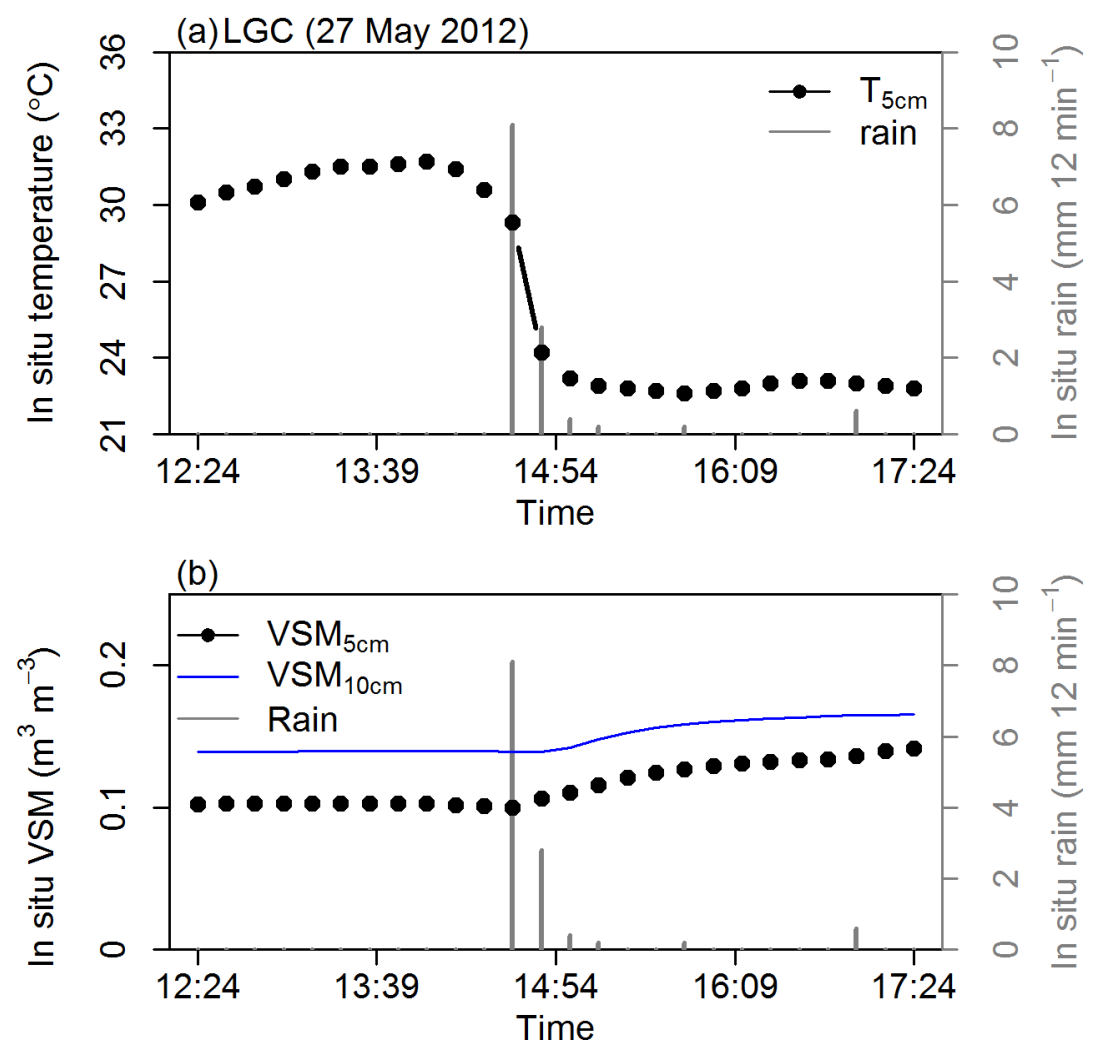

Figure S16. (a) In situ $\mathrm{T}_{5 \mathrm{~cm}}$ (black) and rainfall (grey) observations, and (b) in situ $\mathrm{VSM}_{5 \mathrm{~cm}}$ (black), $\mathrm{VSM}_{10 \mathrm{~cm}}$ (blue) and rainfall (grey) observations are measured every 12 min at LGC station on 27 May 2012. 

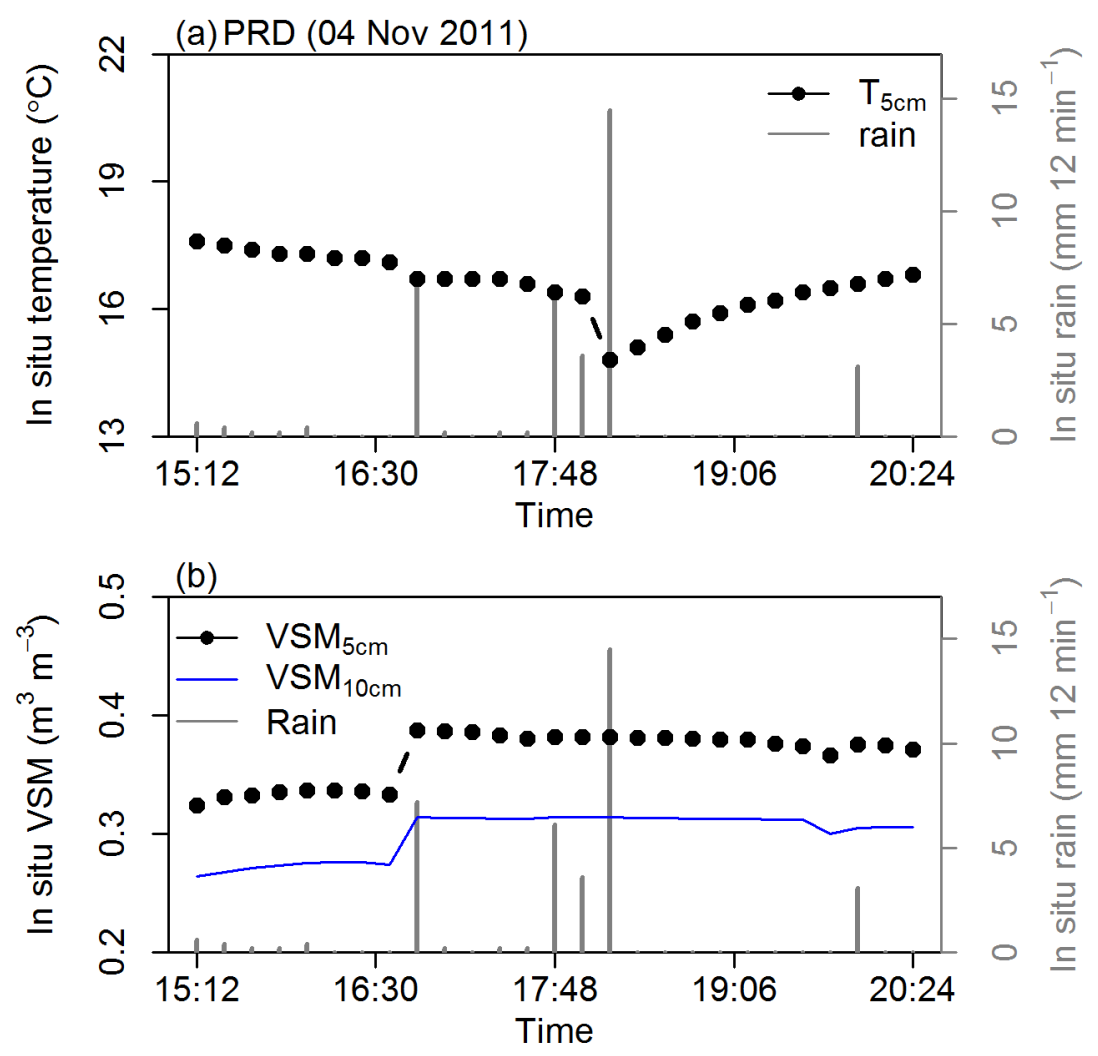

Figure S17. (a) In situ $\mathrm{T}_{5 \mathrm{~cm}}$ (black) and rainfall (grey) observations, and (b) in situ $\mathrm{VSM}_{5 \mathrm{~cm}}$ (black), $\mathrm{VSM}_{10 \mathrm{~cm}}$ (blue) and rainfall (grey) observations are measured every $12 \mathrm{~min}$ at PRD station on 4 November 2011. 

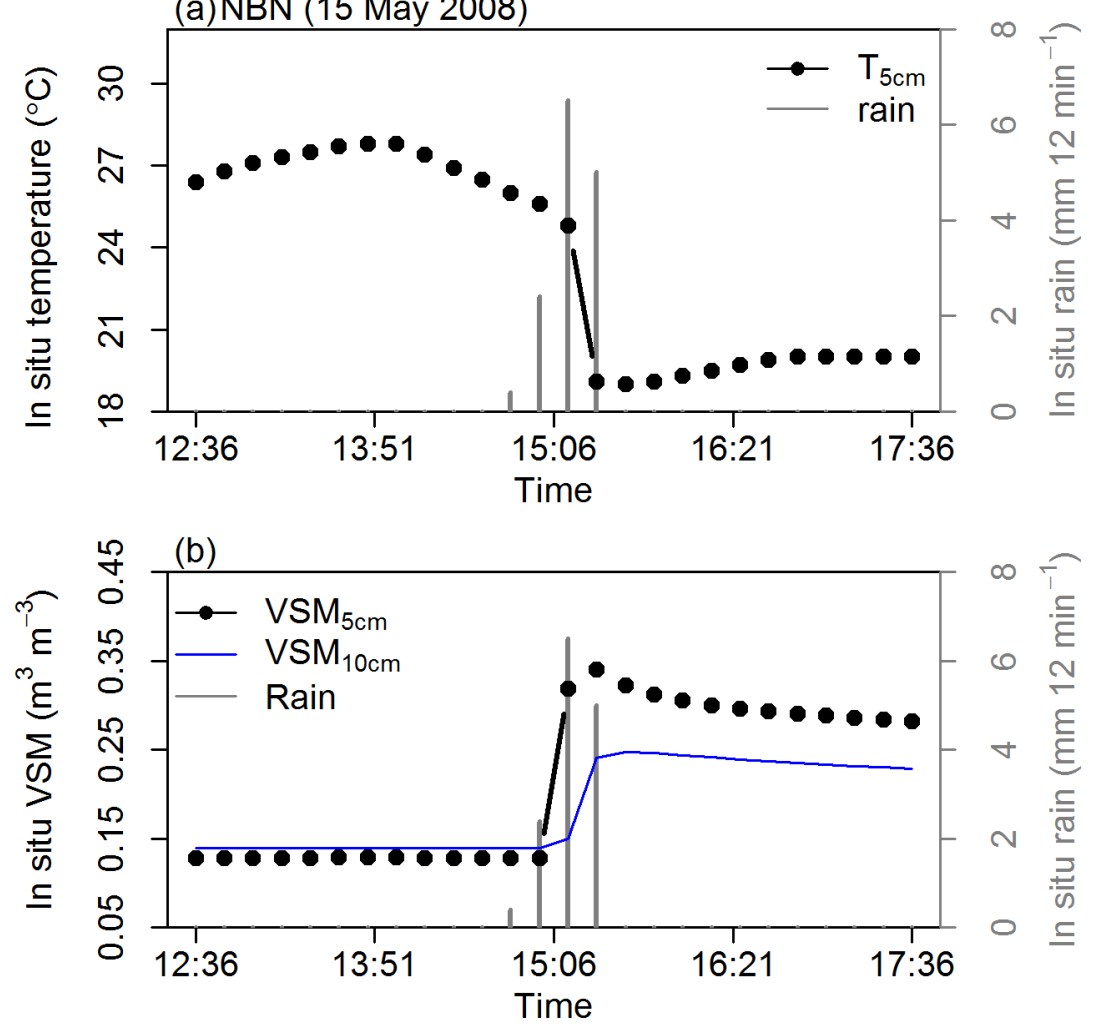

Figure S18. (a) In situ $\mathrm{T}_{5 \mathrm{~cm}}$ (black) and rainfall (grey) observations, and (b) in situ $\mathrm{VSM}_{5 \mathrm{~cm}}$ (black), $\mathrm{VSM}_{10 \mathrm{~cm}}$ (blue) and rainfall (grey) observations are measured every 12 min at NBN station on 15 May 2008. 

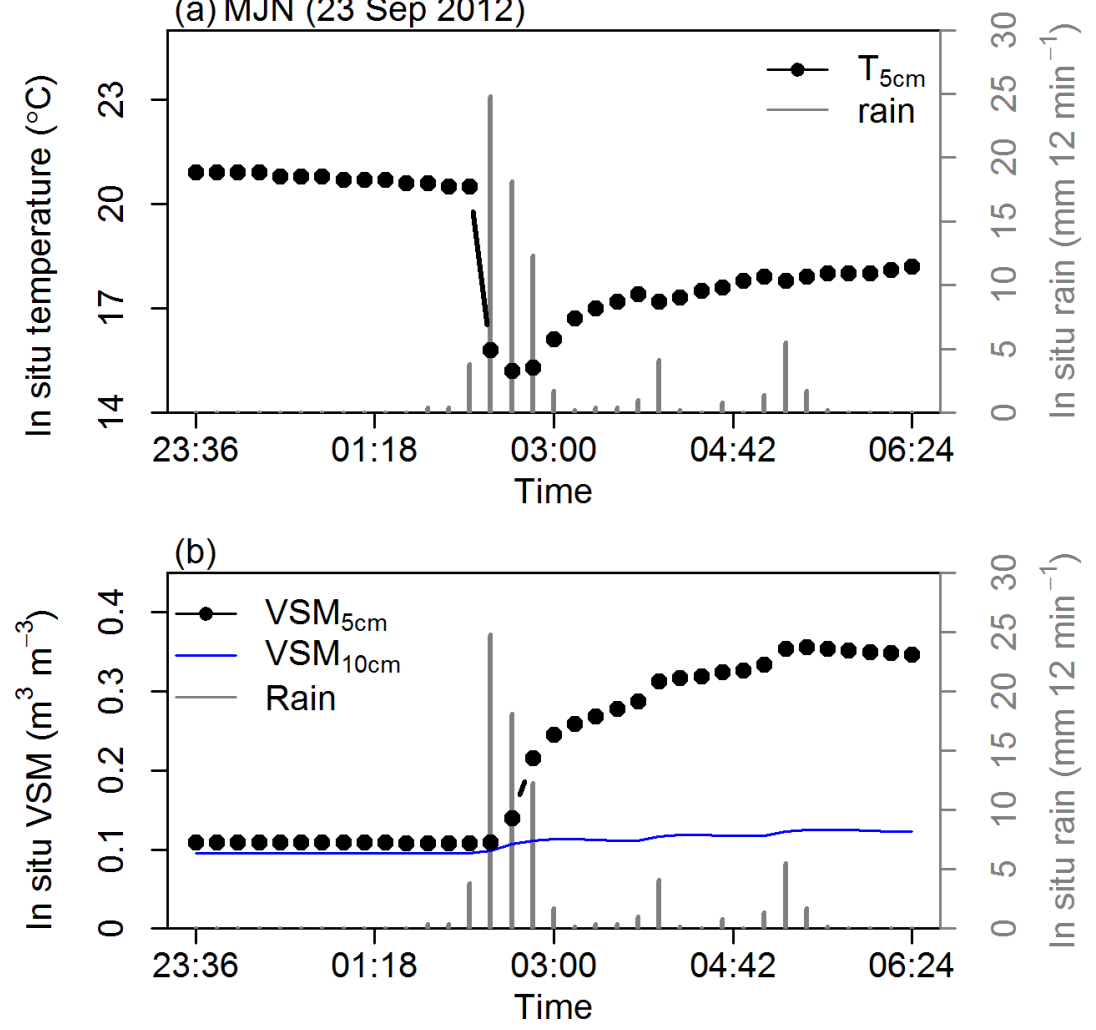

Figure S19. (a) In situ $\mathrm{T}_{5 \mathrm{~cm}}$ (black) and rainfall (grey) observations, and (b) in situ $\mathrm{VSM}_{5 \mathrm{~cm}}$ (black), $\mathrm{VSM}_{10 \mathrm{~cm}}$ (blue) and rainfall (grey) observations are measured every $12 \mathrm{~min}$ at MJN station on 23 and 24 September 2012. 

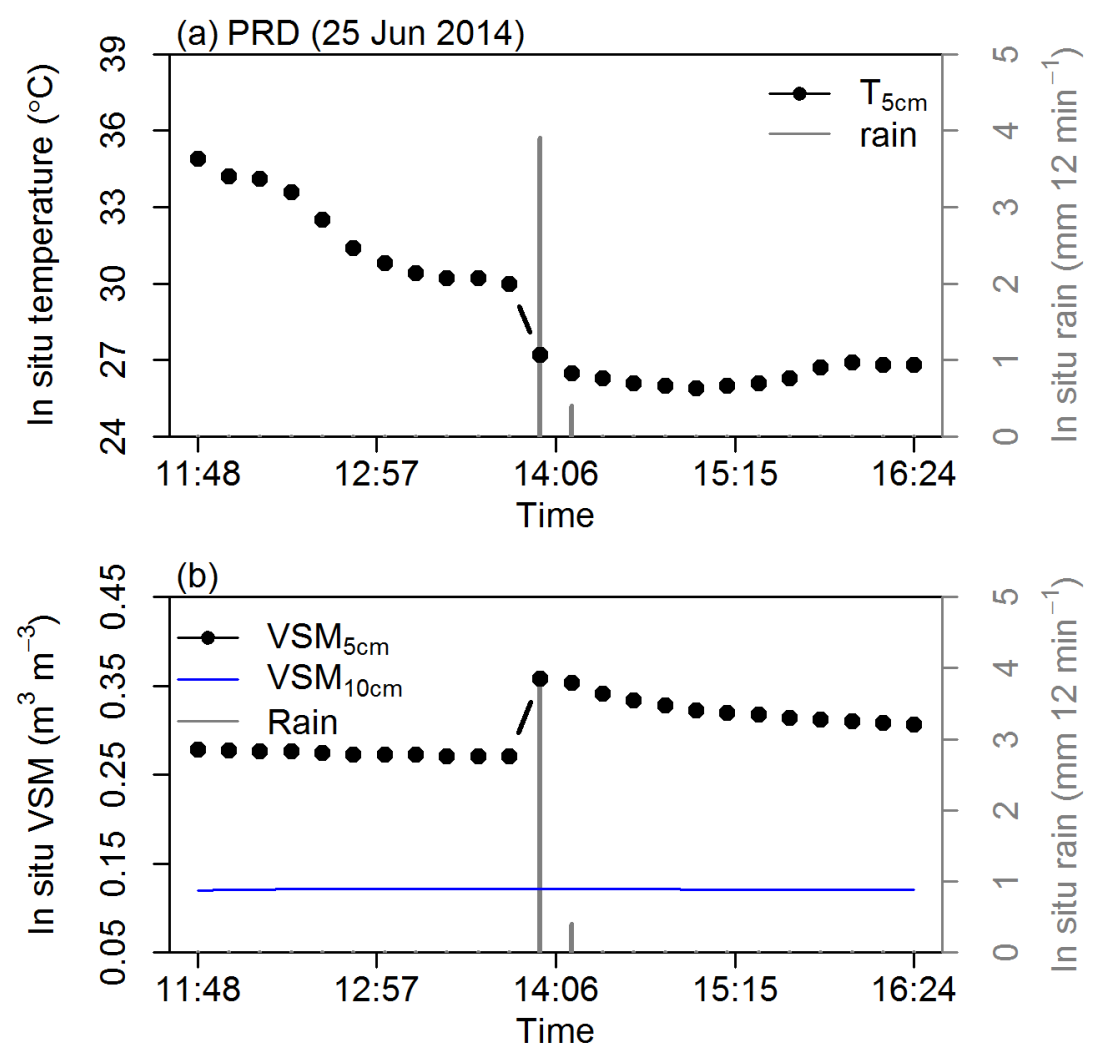

Figure S20. (a) In situ $\mathrm{T}_{5 \mathrm{~cm}}$ (black) and rainfall (grey) observations, and (b) in situ $\mathrm{VSM}_{5 \mathrm{~cm}}$ (black), $\mathrm{VSM}_{10 \mathrm{~cm}}$ (blue) and rainfall (grey) observations are measured every $12 \mathrm{~min}$ at PRD station on 25 June 2014. VSM $\mathrm{Vcm}_{3}$ increase is observed together with the $T_{5 \mathrm{~cm}}$ decrease, but there is no change in $\mathrm{VSM}_{10 \mathrm{~cm}}$, below $0.15 \mathrm{~m}^{3} \mathrm{~m}^{-3}$. 

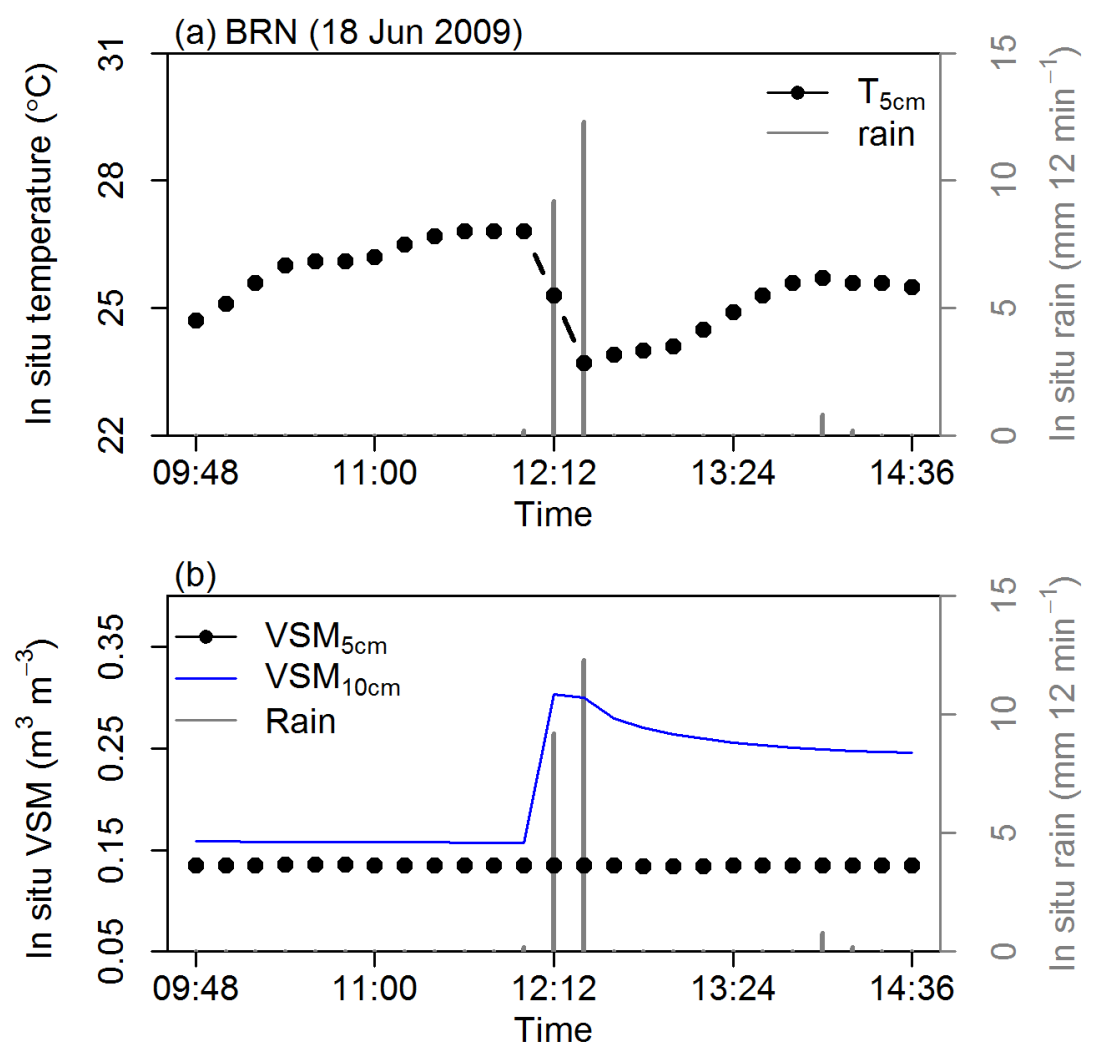

Figure S21. (a) In situ $\mathrm{T}_{5 \mathrm{~cm}}$ (black) and rainfall (grey) observations, and (b) in situ $\mathrm{VSM}_{5 \mathrm{~cm}}$ (black), $\mathrm{VSM}_{10 \mathrm{~cm}}$ (blue) and rainfall (grey) observations are measured every 12 min at BRN station on 18 June 2009. $\mathrm{VSM}_{10 \mathrm{~cm}}$ increase is observed together with the $\mathrm{T}_{5 \mathrm{~cm}}$ decrease, but there is no change in $\mathrm{VSM}_{5 \mathrm{~cm}}$, below $0.15 \mathrm{~m}^{3} \mathrm{~m}^{-3}$. 

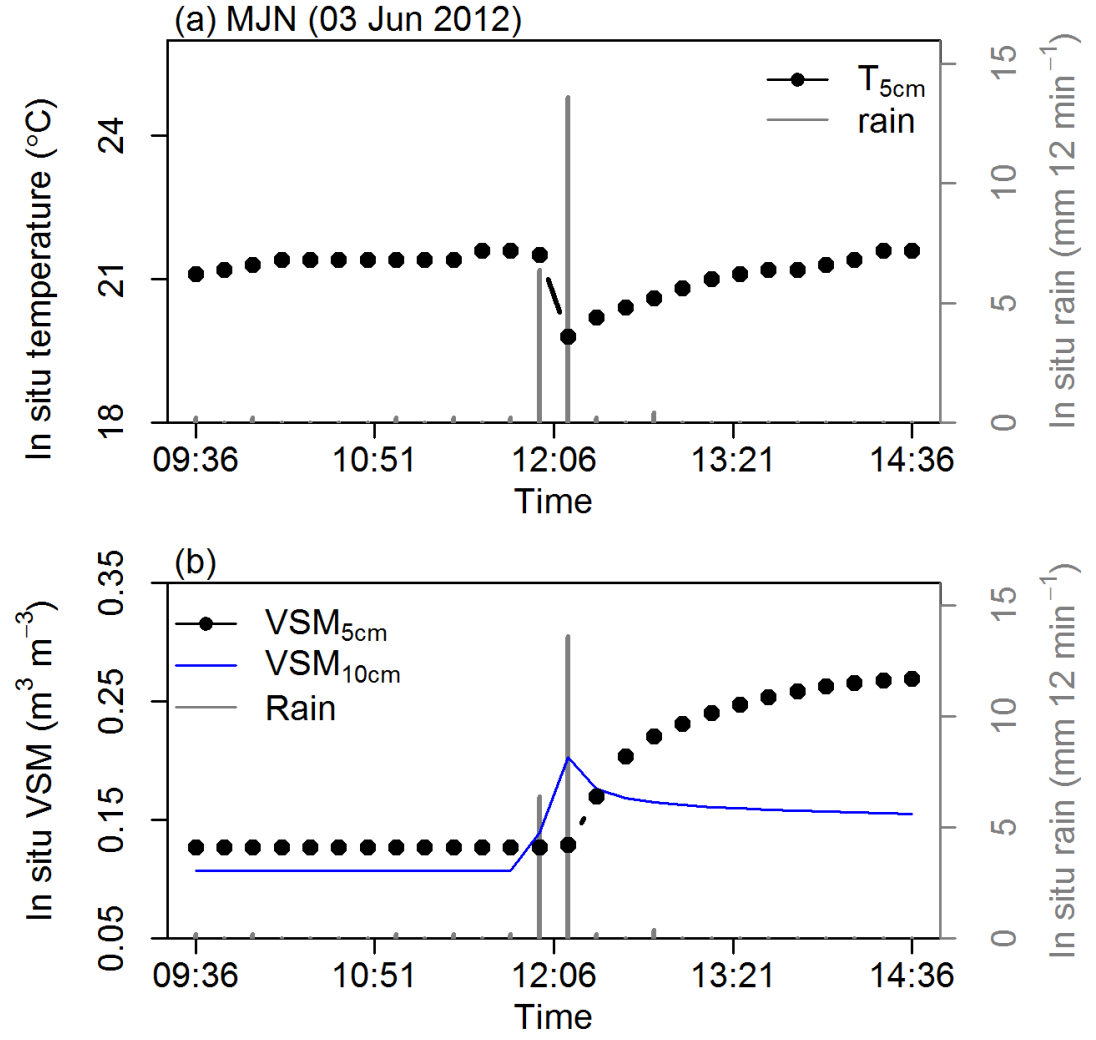

Figure S22. (a) In situ $\mathrm{T}_{5 \mathrm{~cm}}$ (black) and rainfall (grey) observations, and (b) in situ $\mathrm{VSM}_{5 \mathrm{~cm}}$ (black), $\mathrm{VSM}_{10 \mathrm{~cm}}$ (blue) and rainfall (grey) observations are measured every $12 \mathrm{~min}$ at MJN station on 3 June 2012. 


\section{Starting time of intense soil-cooling rains}

Figure S23 investigates the distribution of the starting time of the intense soil-cooling rains at a resolution of 1 hour together with the corresponding average rain rate (in $\mathrm{mm} \mathrm{h}^{-1}$ ) across seasons. For the 4 winter events, the rain rate is relative small (less than $7.5 \mathrm{~mm} \mathrm{~h}^{-1}$ ). Only 3 events are found with a rain rate larger than $50 \mathrm{~mm} \mathrm{~h}^{-1}$, two in summer and one during the autumn. It can be seen that the intense soil-cooling rains tend to occur at daytime. A large proportion (83\%) of the 122 intense soil-cooling rains occur between 09:00 and 21:00 UTC, which is much larger than the fraction of $67 \%$ observed for the 1577 marked rainfall events affecting $T_{5 \mathrm{~cm}}$. The intense soil-cooling rains are rather uniformly distributed between 09:00 and 21:00 UTC.
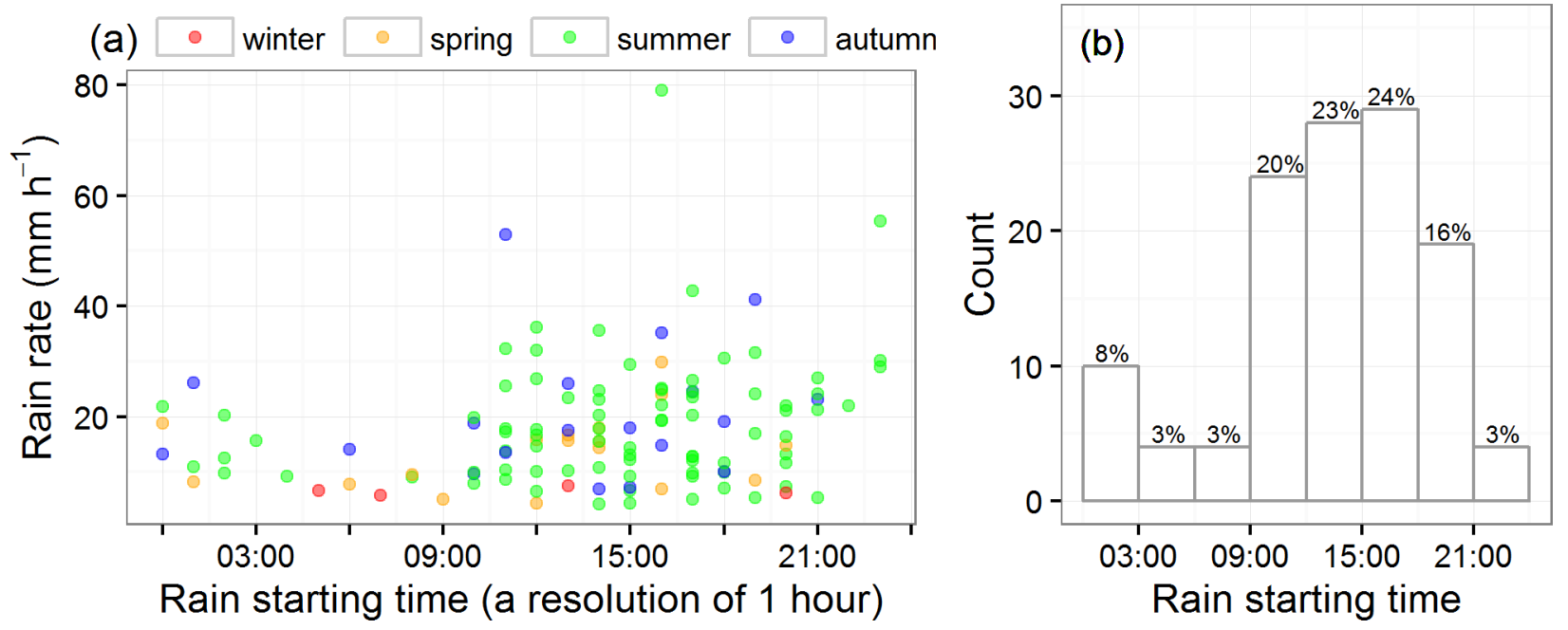

Figure S23. Starting time of the 122 intense soil-cooling rains: vs. rain rate across seasons (a), and statistical distribution with bins of 3 hours (b). 


\section{Examples of ISBA simulations}

Current versions of the ISBA (Interactions between Soil, Biosphere, and Atmosphere) land surface model (LSM) developed by Centre National de Recherches Météorologiques (CNRM) neglect the precipitation-induced sensible heat flux. Soil temperature and VSM simulations at depths of 5, 10, 20 and $30 \mathrm{~cm}$ were performed using the ISBA LSM within the SURFEX (version 8.0) modeling platform (Masson et al., 2013). The ISBA configuration and the hourly SAFRAN atmospheric analysis (Durand et al., 1993, 1999) we used to force the model at a spatial resolution of $8 \mathrm{~km} \times 8 \mathrm{~km}$ are described in Lafont et al. (2012) and Decharme et al. (2013). ISBA simulations of topsoil soil moisture and soil temperature profiles for the grassland plant functional type are considered.

Figure S24 presents the ISBA numerical simulations of soil temperature and soil moisture at the PRD station from 21 to 25 August 2015 at depths of 5, 10, 20 and $30 \mathrm{~cm}$. Since ISBA does not represent the heat exchange caused by the mass movement of rainwater, the simulated topsoil temperature is only driven by the surface energy budget, including the evaporation of rainwater intercepted by the vegetation, and by heat conduction from deeper soil layers. As a result, almost no soil temperature change is simulated while changes in soil moisture in response to the rain are simulated. In this example, the rainfall event as a whole is represented well by the SAFRAN atmospheric forcing used to force the ISBA model. In SAFRAN, the rainfall event lasts for $14 \mathrm{~h}$, starting at 10:00 UTC and ending at 23:00 UTC. Over this period of time, the accumulated rainfall of SAFRAN rain is $86.4 \mathrm{~mm}$, very close to the observed accumulated rainfall of in situ rain of $86.1 \mathrm{~mm}$ (note that this time period differs from the one used in Table 5). However, SAFRAN is not able to represent the sub-hourly variability of rainfall intensity. While the observed peak rainfall intensity value is $27.8 \mathrm{~mm}$ in 12 minutes at 12:36 UTC (Figure 2), SAFRAN indicates a rather constant intensity of about 6 $\mathrm{mm} \mathrm{h}^{-1}$. The shown ISBA simulations represent the current state of hourly operational land surface monitoring, available over whole of metropolitan France. This means that the best possible operational simulations currently available are not able to represent the impact of intense precipitation on the soil temperature profile. The ISBA land surface model needs to be improved. The SAFRAN atmospheric analysis could also probably be improved by using more in situ observations together with high resolution atmospheric simulations.
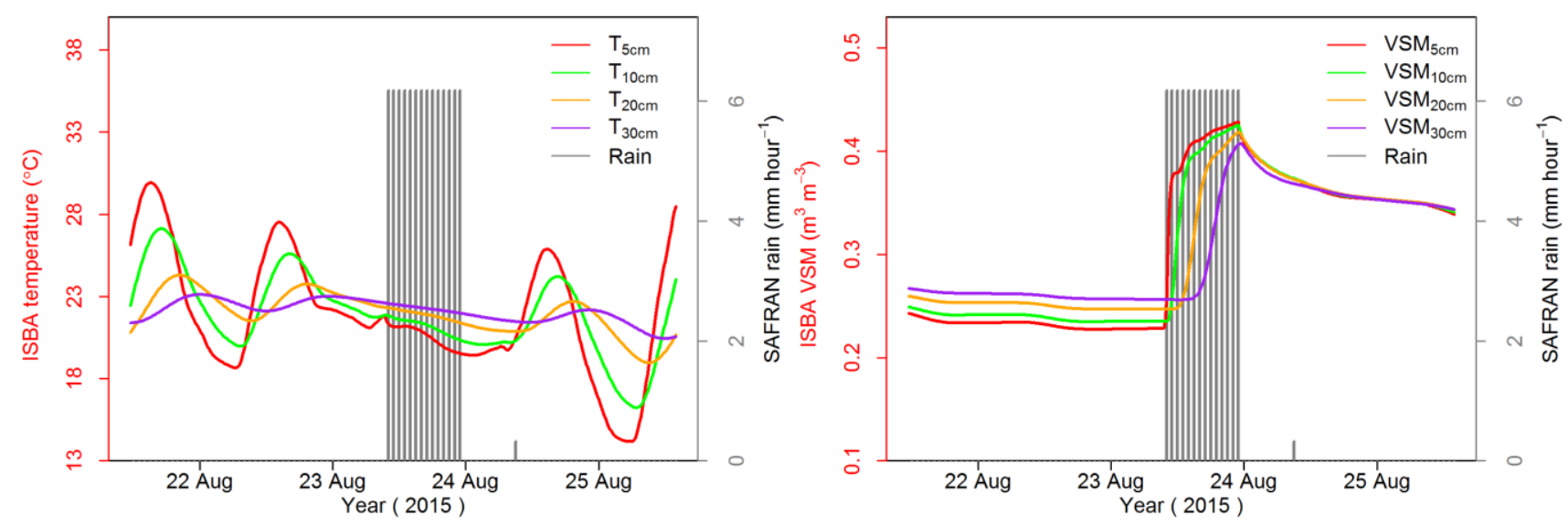

Figure S24. ISBA simulations of soil temperature (left) and soil moisture (right) at the PRD station from 21 to 25 August 2015 at depths of 5, 10, 20 and $30 \mathrm{~cm}$, together with the SAFRAN rainfall data (mm hour-1) shown in grey. 
Figure S25 presents the statistical distribution of minimum $\Delta T_{5 \mathrm{~cm}}$ observations, and the corresponding minimum $\Delta T_{5 \mathrm{~cm}}$ values simulated by the ISBA model for the 1577 marked rainfall events affecting $T_{5 \mathrm{~cm}}$. It appears that step 5 tends to remove the longest rainfall events and the selected rainfall events last less than 4 hours. The comparison between observed and simulated values shows that ISBA is not able to simulate $\Delta T_{5 \mathrm{~cm}}$ values well. In particular, most of the simulated minimum $\Delta T_{5 \mathrm{~cm}}$ values do not depart much from $0{ }^{\circ} \mathrm{C}$ in 12 minutes during intense soil-cooling events, even for very intense ones with observed minimum $\Delta T_{5 \mathrm{~cm}}$ values lower than $-4{ }^{\circ} \mathrm{C}$ in 12 minutes. Figure S25 also shows that most of the 122 intense soil-cooling events occur in $\mathrm{M}$ or in MM climate conditions.
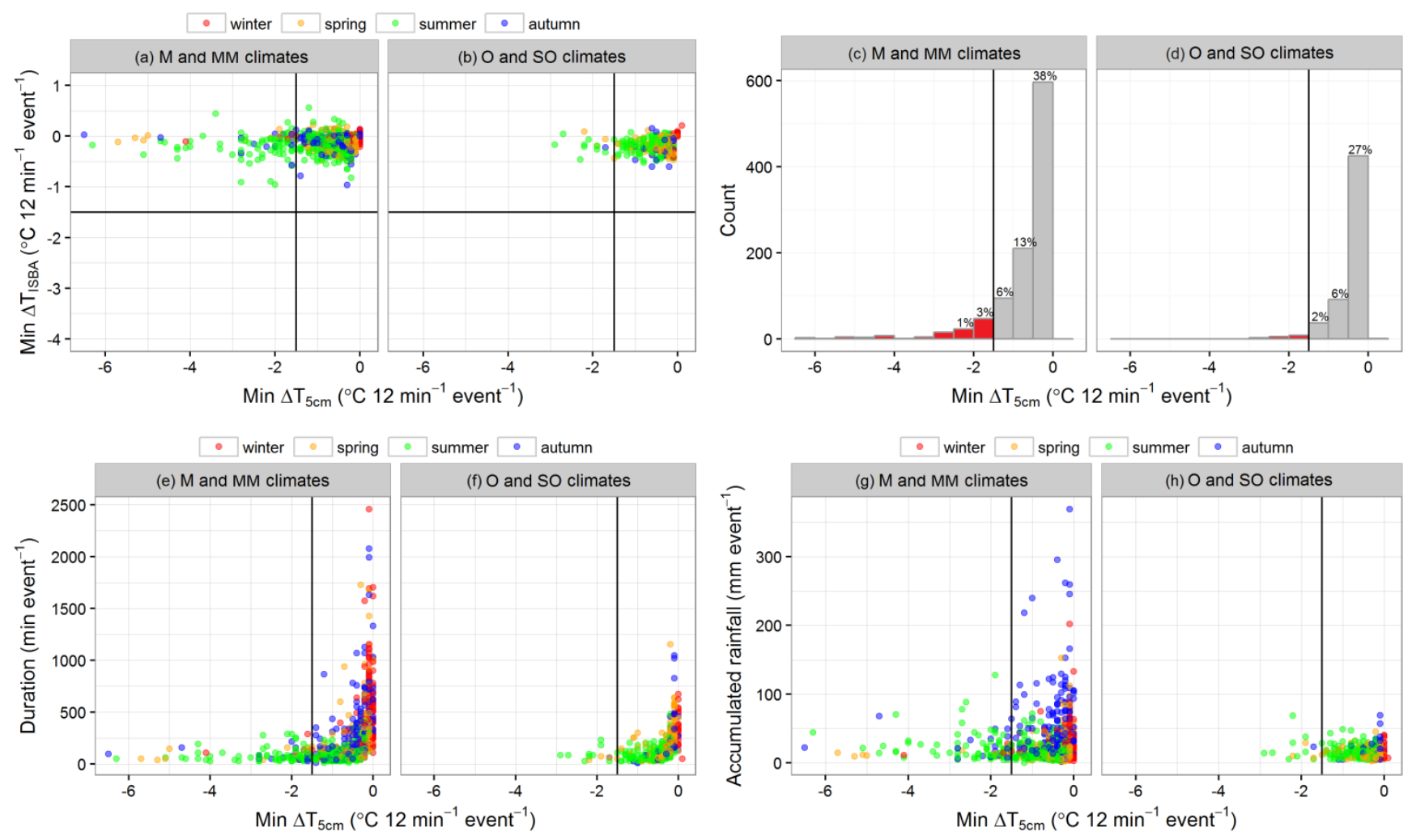

Figure S25. Minimum $\Delta T_{5 \mathrm{~cm}}$ during 1577 marked rainfall events affecting $T_{5 \mathrm{~cm}}$ : vs. minimum $\Delta T_{\text {ISBA }}$ $(a, b)$, statistical distribution (bins of $\left.0.5^{\circ} \mathrm{C}\right)(\mathrm{c}, \mathrm{d})$, vs. rain duration (e, f), and vs. the accumulated rainfall ( $\mathrm{g}, \mathrm{h}$ ), for Mediterranean (M) and Mediterranean-mountain (MM) stations (a, c, e, g) and for oceanic (O) and semi-oceanic (SO) stations (b, d, f, h). Dark lines are for the $-1.5{ }^{\circ} \mathrm{C}$ threshold for intense soil-cooling rains (step 5 in Table 2). 


\section{References}

Durand, Y., Brun, E., Mérindol, L., Guyomarc'h, G., Lesaffre, B., and Martin, E.: A meteorological estimation of relevant parameters for snow models, Ann. Geophys., 18(1), 65-71, https://doi.org/doi:10.1017/S0260305500011277, 1993.

Durand, Y., Giraud, G., Brun, E., Merindol, L., and Martin, E.: A computer-based system simulating snow-pack structures as a tool for regional avalanche forecasting, Ann. Glaciol., 45(151), 469-484, https://doi.org/doi:10.1017/S0022143000001337, 1999.

Lafont, S., Zhao, Y., Calvet, J.-C., Peylin, P., Ciais, P., Maignan, F., and Weiss, M.: Modelling LAI, surface water and carbon fluxes at high-resolution over France: comparison of ISBA-A-gs and ORCHIDEE, Biogeosciences, 9, 439-456, https://doi.org/10.5194/bg-9-439-2012, 2012.

Masson, V., Le Moigne, P., Martin, E., Faroux, S., Alias, A., Alkama, R., Belamari, S., Barbu, A., Boone, A., Bouyssel, F., Brousseau, P., Brun, E., Calvet, J.-C., Carrer, D., Decharme, B., Delire, C., Donier, S., Essaouini, K., Gibelin, A.-L., Giordani, H., Habets, F., Jidane, M., Kerdraon, G., Kourzeneva, E., Lafaysse, M., Lafont, S., Lebeaupin Brossier, C., Lemonsu, A., Mahfouf, J.-F., Marguinaud, P., Mokhtari, M., Morin, S., Pigeon, G., Salgado, R., Seity, Y., Taillefer, F., Tanguy, G., Tulet, P., Vincendon, B., Vionnet, V., and Voldoire, A.: The SURFEXv7.2 land and ocean surface platform for coupled or offline simulation of earth surface variables and fluxes, Geosci. Model Dev., 6, 929-960, https://doi.org/10.5194/gmd-6-929-2013, 2013. 